American University Washington College of Law

Digital Commons @ American University Washington College of

Law

Contributions to Books

Scholarship \& Research

2018

\title{
Climate Change Innovation, Products and Services under the GATT/WTO System
}

\author{
Padideh Ala'i \\ American University Washington College of Law, palai@wcl.american.edu \\ David Gantz
}

Follow this and additional works at: https://digitalcommons.wcl.american.edu/facsch_bk_contributions

Part of the Environmental Law Commons, and the Intellectual Property Law Commons

\section{Recommended Citation}

Ala'i, Padideh and Gantz, David, "Climate Change Innovation, Products and Services under the GATT/WTO System" (2018). Contributions to Books. 116.

https://digitalcommons.wcl.american.edu/facsch_bk_contributions/116

This Book Chapter is brought to you for free and open access by the Scholarship \& Research at Digital Commons @ American University Washington College of Law. It has been accepted for inclusion in Contributions to Books by an authorized administrator of Digital Commons @ American University Washington College of Law. For more information, please contact kclay@wcl.american.edu. 
RESEARCH HANDBOOK ON

Intellectual Property

and Climate Change

Edited by

Joshua D. Sarnoff

RESEARCH HANDBOOKS IN INTELLECTUAL PROPERTY 


\section{RESEARCH HANDBOOK ON Intellectual Property and Climate Change}

Tackling the climate problem will require the development, deployment and itransfer of a wide variety of technologies at a pace and scale unprecedented outside of wartime. This will involve not only the environmental, energy and treaty laws familiar to climate law specialists, but also a bewildering array of issues under intellectual property, trade, procurement and other legal fields. Joshua Sarnoff has done a wonderful job in assembling leading experts from around the world to illuminate

Michael B.Gemard-Columbia complex matters.

In the wake of the Paris Agreement, there is a great need to encourage a transition to a clean energy world economy. Intellectual property and innovation policy will play a critical role in research, development, and deployment of clean technologies. In this context, the Research Handbook on Intellectual Property and Climate Change, edited by Joshua Sarnoff, is essential reading.

This landmark collection provides a comprehensive examination of the inter-relationship between intellectual property and climate change. Leading authors from around the world tackle topics such as international law, patent law, green trade marks, copyright law, and trade secrets law. The Research Handbook on Intellectual Property and Climate Change also considers larger public policy issues in respect of climate finance, innovation law and policy, government procurement, standard-seiting, and competition law.

Matthew Rimmer, Queensland University of Technology, Australiz

The December 2015 Paris climate change agreement brings into sharp focus the relationship between technology innovation and transfer and greenhouse gas emission mitigation. But, the

international climate change regime, such as it is, has barely addressed these issues. Thus, efforts to innovate and to broaden access to technology must take place in the context of international intellectual property and trade regimes which are more concerned

with protecting intellectual property than in promoting broader access. The Research Handbook on Intellectual Property and

Climate Change could not be more timcly. A group of leading

scholars have developed a comprehensive analysis of the

relevant issues at the intersection of energy policy and IP law

and policy. Those diving into the field for the first time will find comprehensive introduction to all the issues not available anywhere

else. Specialists in various aspects of IP or energy law will gain a clear understanding of the problems of integrating the two regimes as well as a wealth of detail of how the existing regimes have worked in practice. The Research Handbook would also make a good supplement for a climate change class. Dan Tarlock, Chicago-Kent College of Law, USA

Written by a global group of leading scholars, this wideranging Research Handbook provides insightful analysis, useful historical perspective, and a point of reference on the controversial nexus of climate change law and policy, intellectual property law and policy, innovation policy, technology transfer. and trade.

The contributors provide a unique review of the scientific background, international treaties, and political and institutional contexts of climate change and intellectual property law. They further identify critical conflicts and differences of approach between developed and developing countries. Finally they put forward and analyse the relevant intellectual property law doctrines and policy options for funding. developing, disseminating, and regulating the required technologies and associated activities and business practices

The book will serve as a resource and reference tool for scholars, policymakers, and practitioners looking to understand the issues at the intersection of intellectual property and climate change.

\section{Joshua D. Sarnoff is}

Professor of Law at DePaul University College of Law, USA.

\section{Edward Elgar \\ PUBLISHING}

The Lypiatts, 15 Lansdown Road, Cheltentiam, Glos GL50 2JA, UK Tel: +44 (0) 1242.226934 Fax: +44 (0) 1242.262111 F.mail: infoge-elgar.co.uk

William Pratt House, 9 Dewwy Count, Northamptun, MA 01060, USA Tel: +14135845551 Fax +14135849933 Eraial elgarinforge-elgar.com

ISBN 978-1-84980-467-7

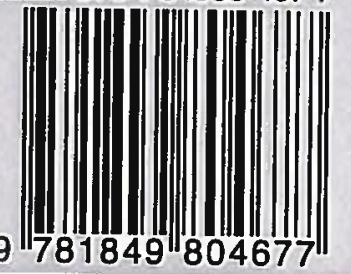




\section{Research Handbook on Intellectual Property and Climate Change}

Edited by

Joshua D. Sarnoff

Professor of Law, DePaul University College of Law, USA

RESEARCH HANDBOOKS IN INTELLECTUAL PROPERTY

\section{E. $\underset{\text { PUBLISHING }}{\text { Edigard Elgar }}$}

Cheltenham, UK • Northampton, MA, USA 


\section{RESEARCH HANDBOOKS IN INTELLECTUAL PROPERTY}

Series Editor: Jeremy Phillips, Intellectual Property Consultant, Olswang, Research Director; Intellectual Property Institute and co-founder; IPKat weblog

Under the general editorship and direction of Jeremy Phillips comes this important new Handbook series of high quality, original reference works that cover the broad pillars of intellectual property law: trademark law, patent law and copyright law - as well as less developed areas, such as geographical indications, and the increasing intersection of intellectual property with other fields. Taking an international and comparative approach, these Handbooks, each edited by leading scholars in the respective field, will comprise specially commissioned contributions from a select cast of authors, bringing together renowned figures with up-and-coming younger authors. Each will offer a wide-ranging examination of current issues in intellectual property that is unrivalled in its blend of critical, innovative thinking and substantive analysis, and in its synthesis of contemporary research.

Each Handbook will stand alone as an invaluable source of reference for all scholars of intellectual property, as well as for practising lawyers who wish to engage with the discussion of ideas within the field. Whether used as an information resource on key topics, or as a platform for advanced study, these Handbooks will become definitive scholarly reference works in intellectual property law.

Titles in the series include:

Criminal Enforcement of Intellectual Property

A Handbook of Contemporary Research

Edited by Christophe Geiger

Research Handbook on Cross-border Enforcement of Intellectual Property Edited by Paul Torremans

Research Handbook on Human Rights and Intellectual Property

Edited by Christophe Geiger

International Intellectual Property

A Handbook of Contemporary Research

Edited by Daniel J. Gervais

Indigenous Intellectual Property

A Handbook of Contemporary Research

Edited by Matthew Rimmer

Research Handbook on Intellectual Property and Geographical Indications Edited by Dev S. Gangjee

The History of Copyright Law

A Handbook of Contemporary Research

Edited by lsabella Alexander and H. Tomás Gómez-Arostegui

Research Handbook on Intellectual Property and Climate Change

Edited by Joshua D. Sarnoff 
(C) The Editor and Contributors Severally 2016

All rights reserved. No part of this publication may be reproduced, stored in a retrieval syster or transmitted in any form or by any means, electronic, mechanical or photocopying, recordir or otherwise without the prior permission of the publisher.

Published by

Edward Elgar Publishing Limited

The Lypiatts

15 Lansdown Road

Cheltenham

Glos GL50 2JA

UK

Edward Elgar Publishing, Inc.

William Pratt House

9 Dewey Court

Northampton

Massachusetts 01060

USA

A catalogue record for this book

is available from the British Library

Library of Congress Control Number: 2015957862

This book is available electronically in the Elgaronline

Law subject collection

DOI $10.4337 / 9781784719463$

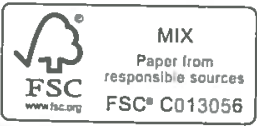

ISBN 9781849804677 (cased)

ISBN 978 I 784719463 (eBook)

Typeset by Columns Design XML Ltd, Reading

Printed and bound in Great Britain by TJ International Ltd, Padstow 


\section{Contents}

List of contributors

vii

1 Introduction

Joshua D. Sarnoff

2 Climate science and policy responses 11

David Hunter

3 International law and institutions for climate change

Sanford E. Gaines

4 Climate change, the international intellectual property régime, and disputes under the TRIPS Agreement

Daniel J. Gervais

5 Intellectual property rights under the UNFCCC: without response to developing countries' concerns

Carlos $M$. Correa

6 The intellectual property regime: are there lessons for climate change negotiations?

Peter Drahos

7 Intellectual property enforcement and global climate change

Peter $K . Y_{l l}$

8 Beyond technology transfer: protecting human rights in a climateconstrained world.

The International Council on Human Rights Policy

9 Behind the wall: global climate change and American religion

Robert K. Musil

10 Technology transfer for climate change and developing country viewpoints on historical responsibility and common but differentiated responsibilities

Dalindyebo Shabalala

11 Government choices in innovation funding

Joshua D. Samoff

12 Catalyzing technology development through university research Jorge L. Contreras and Charles R. McManis

13 Antitrust and climate change

Michael A. Carrier

14 Climate change innovation, products and services under the GATT/WTO system

David A. Gantz and Padideh Ala'i

15 The role of government procurement in regard to development, dissemination and costs of climate change technologies

Denis Borges Barbosa and Charlene de Avila Plaza 
vi Research handbook on intellectual property and climate change

16 Patents and climate change

Joshua D. Sarnoff

17 Trade secrets and climate change: uncovering secret solutions to the problem of greenhouse gas emissions

Sharon K. Sandeen and David S. Levine

18 The role of copyright in the protection of the environment and the fight against climate change: is the current copyright system adequate? Estelle Derclaye

19 Intellectual property and related rights in climate data Michael W. Carroll

20 Green marks Christine Haight Farley

21 Standards and related intellectual property issues for climate change technology

Jorge L. Contreras

22 Privacy issues in smart grid deployment

Jennifer M. Urban

23 Energy

Steven Ferrey

24 Transportation

Paolo Bifani, David Vivas-Eugui and Haifeng Wang

25 Food

Geoff Tansey

26 Natural resources

Baskut Tuncak

Index 
Padideh Ala'i is a Professor of Law and the Director of the Humphrey Fellowship Program at American University, Washington College of Law. She specializes in areas of international economic law and comparative legal traditions, teaches the law of the World Trade Organization (WTO), and writes in the areas of history and free trade, international efforts to combat corruption, transparency and good governance. She received her JD from Harvard Law School in 1988 and from 1988-1997 was in private legal practice. Her publications include the Research Handbook on Transparency (Edward Elgar Publishing 2014) (co-edited with Robert Vaughn) and numerous law review articles on trade, the WTO, and corruption.

Charlene de Avila Plaza has a Master of Laws in the area of Integration and Industrial Relations from the University of Ribeirão Preto - São Paulo-UNAERP - Brasil, LLM. She is a legal consultant in intellectual property matters at Denis Borges Barbosa Office - Rio de Janeiro

Denis Borges Barbosa, LLB, LLM, LLM, JSD, Catholic University of Rio de Janeiro, has acted as a consultant to the Government of Brazil on the issue of use of Public Contracts to develop technology.

Paolo Bifani is an Italian economist. He is a former staff member of the UN Economic Commission for Latin America and the Caribbean (ECLAC), UN Environment Programme (UNEP), United Nations Conference on Trade and Development (UNCTAD), and World Intellectual Property Rights Organization (WIPO). He has been a consultant to many intergovernmental organizations and universities, and has published extensively on trade, environment and intellectual property topics, including reports of restricted circulation. His books and many book chapters include Medio Ambiente y Desarrollo (7th edn), La Globalización ¿otra Caja de pandora? (2nd edn), and 'Globalization, Spatial Scales and Decision Making Implications for Land Use' in Global Land Use Changes (SCOPE-CSIC).

Michael A. Carrier is a Distinguished Professor at Rutgers Law School. He is the author of Innovation for the 21st Century: Harnessing the Power of Intellectual Property and Antitrust Law and the editor of Critical Concepts in Intellectual Property Law: Competition. He has written more than 75 book chapters and articles in leading law reviews, and has been quoted in numerous media outlets. His scholarship has been cited in courts including the US Supreme Court and federal appellate courts.

Michael W. Carroll is a Professor of Law and Director of the Program on Information Justice and Intellectual Property at American University Washington College of Law. His research and teaching specialties are intellectual property law and cyberlaw, focusing on the search for balance in the face of challenges posed by new technologies. $\mathrm{He}$ is a founding member of Creative Commons, Inc., serves on the Board of Directors 
of the Public Library of Science and recently completed service on the National Research Council's Board on Research Data and Information. He also is an Academic Fellow of the Center for Democracy and Technology.

Jorge L. Contreras (JD Harvard Law School; BSEE, BA Rice University) is an Associate Professor of Law at the University of Utah S.J. Quinney College of Law and a Senior Policy Fellow in the Program on Information Justice and Intellectual Property at American University Washington College of Law. He has written and spoken extensively on the institutional structures of intellectual property, technical standardization and biomedical research. He currently serves as a member of the Advisory Council of NIH's National Center for the Advancement of Translational Sciences (NCATS), and previously served as Co-Chair of the National Conference of Lawyers and Scientists and a member of the National Advisory Council for Human Genome Research.

Carlos M. Correa is the Director of the Center for Interdisciplinary Studies on Industrial Property and Economics at the Law Faculty, University of Buenos Aires, and a Special Advisor on Trade and Intellectual Property of the South Centre. Dr Correa has been consultant to several international and regional organizations and national governments on intellectual property, innovation and transfer of technology issues. $\mathrm{He}$ contributed to the UNDP report Technological Cooperation and Climate Change: Issues and Perspectives (UNDP, New Delhi, 2011) on mechanisms for international cooperation in research and development in the area of climate change.

Estelle Derclaye is a Professor of Intellectual Property Law at the University of Nottingham. She is the author and editor of several books in the field of IP law and has done expert work for the UK Intellectual Property Office, national and foreign law firms and international organisations. Dr Derclaye was a senior visiting scholar at the University of California, Berkeley in 2010 and at Melbourne Law School in 2013. She is regularly invited to teach and present her research abroad and is one of the pioneers of the study of IP law and climate change.

Peter Drahos is a Professor in the Regulatory Institutions Network at the Australian National University. He holds a Chair in Intellectual Property at Queen Mary, University of London and is a member of the Academy of Social Sciences in Australia.

Christine Haight Farley is a Professor of Law at American University Washington College of Law where she teaches Intellectual Property Law, Trademark Law, International and Comparative Trademark Law, International Intellectual Property Law, Design Protection Law and Art Law. She has also taught at law schools in France, India, Italy and Puerto Rico and has given lectures on intellectual property law in more than twenty countries. Professor Farley currently serves on the INTA Presidential Task Force on Brands and Innovation, and is a Fulbright Specialist for intellectual property law.

Steven Ferrey is a Professor of Law at Suffolk University Law School in Boston, and has served as a Visiting Professor of Law at Harvard Law School and Boston University Law School. He testified as an expert witness before seven different committees of the US Congress on energy, and was appointed by the US President to serve on three different national energy boards. Since 1993, he has served as primary legal advisor to the World Bank and the United Nations on climate change projects in several developing 
countries, and served as Vice-Chair of two different ABA Energy Committees. He is the author of seven books and 100 articles on energy law. In addition to a JD degree from University of California, Berkeley, he holds a BA in economics, a Masters degree in urban and regional energy planning, and was a Fulbright Fellow in London between his graduate degrees.

Sanford E. Gaines, JD cum laude Harvard 1974, had a varied career in environmental law at the Environmental Law Institute, the US EPA, and a US chemical industry trade association before becoming a Law Professor at the University of Houston (1986-2007) and a Visiting Professor at Aarhus University, Denmark (2009-13), with short-term visiting positions in Germany and New Zealand. He served as a senior environmental official in the Office of the US Trade Representative, 1992-94. His publications span diverse topics in US and international environmental law, including air pollution, chemicals regulation, environmental liability, and trade, investment and environment, with a recent focus on climate and renewable energy law.

David A. Gantz, AB (Harvard College), JD, JSM (Stanford Law School), is the Samuel M. Fegtly Professor at the University of Arizona, James E. Rogers College of Law, where he teaches and writes in the areas of international trade and investment law, regional trade agreements, public international law and international environmental law. He served earlier in the Office of the Legal Adviser, US Department of State and practiced law in Washington, DC. Gantz is the author or co-author of four books and more than 50 law review articles and book chapters, has served as a consultant for the UNDP, USAID and the World Bank, among others, and as a panelist under Chapters 11, 19 and 20 of NAFTA. His most recent book is Liberalizing International Trade after Doha: Multilateral, Plurilateral, Regional and Unilateral Initiatives (Cambridge University Press, 2013, 2015).

Daniel J. Gervais is a Professor of Law at Vanderbilt University Law School and Director of the Vanderbilt Intellectual Property Program. He is Editor-in-Chief of the Journal of World Intellectual Property and editor of www.tripsagreement.net. He has been the Acting Dean, University Research Chair in Intellectual Property at the University of Ottawa, Legal Officer at the GATT (now the WTO); Head of Section at WIPO; and Vice-President of Copyright Clearance Center, Inc. (CCC). After studies in computer science, Dr Gervais attended law school at McGill University, and the University of Montreal, where he obtained LLB and LLM degrees. He also received a Diploma summa cum laude from the Institute of Advanced International Studies in Geneva, and a doctorate magna cum laude from the University of Nantes (France). He was the first law professor in North America elected to the Academy of Europe. He is a member of the American Law Institute.

David Hunter is a Professor of Law, Director of the International Legal Studies Program and Director of the Program on International and Comparative Environmental Law at American University's Washington College of Law. He is a Member Scholar of the Center for Progressive Reform, a member of the Organization of American States' Expert Group on Environmental Law, the Steering Committee of the IUCN World Commission on Environmental Law, and the Strategic Advisors Group for the International Finance Corporation's Compliance Advisor/Ombudsman's Office. 
The International Council on Human Rights Policy (ICHRP) was first conceived in 1994 by a group of eminent human rights advocates, scholars and policy makers, and was established in Geneva in 1998 to conduct applied research into current human rights issues. Its research was designed to be of practical relevance to policy makers in international and regional organisations, in governments and inter-governmental agencies, and in voluntary organisations of all kinds. The ICHRP was independent, international in its membership, and participatory in its approach. It was registered as a non-profit foundation under Swiss law. Between 1998 and 2012, it undertook 35 major research projects addressing a wide range of policy questions and providing a forum for applied research, reflection and forward thinking. In February 2012, the decision was taken to close the ICHRP as a result of the difficult economic conditions. Its reports and related materials can be found on-line.

David S. Levine is an Associate Professor of Law at Elon University School of Law and an Affiliate Scholar at the Center for Internet and Society (CIS) at Stanford Law School. For 2015-2016, he is a Visiting Research Collaborator at Princeton University's Center for Information Technology Policy. His research interests include the operation of intellectual property law at the intersection of the technology field and public life, intellectual property's impact on transparency, and information systems and access. $\mathrm{He}$ is also the founder and host of Hearsay Culture on KZSU-FM (Stanford University).

Charles R. McManis is the Thomas and Karole Green Professor of Law Emeritus and former Director of the Intellectual Property \& Technology Law Program at Washington University in St. Louis, Missouri. He received a BA from Birmingham-Southern College, and an MA (in Philosophy) and JD from Duke University. He was a Fulbright Fellow in Korea, and has served as a consultant for the World Intellectual Property Organization in India, Korea and Oman. His books include Intellectual Property \& Unfair Competition in a Nutshell (a 7 th edn is being prepared), Licensing Intellectual Property in the Information Age (2nd edn, 2005), and Biodiversity and the Law: Intellectual Property, Biotechnology and Traditional Knowledge (2007).

Robert K. Musil, PhD, MPH is President of the Rachel Carson Council and Senior Fellow at the Center for Congressional and Presidential Studies, Amcrican University. He has been a Fellow at the Center for Ethics and Public Policy, Wesley Theological Seminary. Dr Musil was also the longest-serving Executive Director and CEO of Physicians for Social Responsibility (PSR), and winner of the 1985 Nobel Prize for Peace. Musil is the author of Hope for a Heated Planet: How Americans are Fighting Global Warming and Building a Better Future (Rutgers University Press, 2009) and Rachel Carson and Her Sisters: Extraordinary Women Who Have Shaped America's Environment (Rutgers University Press, 2014).

Sharon K. Sandeen is a Professor of Law at Mitchell Hamline School of Law in Saint Paul, Minnesota and an internationally recognized expert on trade secret law. She has written numerous articles and books on the topic, including Trade Secrecy and International Transactions (with E. Rowe). Before beginning her teaching career, Professor Sandeen practiced law for over 15 years as a litigator and intellectual property specialist. She became a full-time professor in 2002 when she joined the faculty of 
Hamline University School of Law. Professor Sandeen earned her JD from the University of Pacific, McGeorge School of Law and her LLM from University of California, Berkeley School of Law.

Joshua D. Sarnoff is a Professor of Law at the DePaul University College of Law, where he focuses on patent law. He is a registered patent attorney, has practiced intellectual property, environmental, and administrative law, and is a former member of the Boards of the Federal Circuit Bar Association and the IP Law Association of Chicago. He has filed amicus briefs on many important patent law issues, and was a consultant to UNCTAD on international IP, trade and environmental issues. From 2014 to 2015, Professor Sarnoff was a Thomas A. Edison Distinguished Scholar at the United States Patent and Trademark Office.

Dalindyebo Shabalala is a Visiting Assistant Professor at Case Western Reserve University Law School and an Assistant Professor, International Economic Law (Intellectual Property) at Maastricht University Faculty of Law. He is also a fellow in the Institute for Globalization and International Regulation (IGIR) at Maastricht University and participates in the Spangenberg Center for Law, Technology \& the Arts at Case Western Reserve. His research focuses on climate change and intellectual property (IP) issues on one hand and on IP and development issues on the other. He also focuses on the role of Brazil, India and China in the regulation of international technology transfer and intellectual property.

Geoff Tansey is an independent writer and consultant. He curates the online Food Systems Academy (www.foodsystemsacademy.org.uk). He is a member of The Food Ethics Council, an Honorary Research Fellow at the University of Bradford's Department of Peace Studies and an Honorary Visiting Fellow at the University of Newcastle's Centre for Rural Economy. He helped found and edit the journal Food Policy in the mid-1970s. His books include The Food System: a guide (with Tony Worsley) and co-editorship of The Future Control of Food - A Guide to International Negotiations and Rules on Intellectual Property, Biodiversity and Food Security.

Baskut Tuncak is a senior attorney at the Center for International Environmental Law (CIEL). He currently serves as the UN Special Rapporteur on human rights and hazardous substances and wastes. Before his legal career, Mr. Tuncak spent several years as a synthetic chemist with small pharmaceutical and synthetic biology companies. In addition, he serves in various advisory roles to both governmental and non-governmental initiatives.

Jennifer M. Urban is a Clinical Professor of Law and Director of the Samuelson Law, Technology \& Public Policy Clinic at the University of California, Berkeley School of Law. Her research considers how liberty values, such as free expression, freedom to innovate and privacy, are mediated by technology, the laws governing technology and private ordering systems. She previously taught at the University of Southern California's Gould School of Law, where she founded and directed the USC Intellectual Property \& Technology Law Clinic. She holds a BA from Cornell University in biological science (neurobiology and behavior) and a JD from Berkeley Law. 


\section{xii Research handbook on intellectual property and climate change}

David Vivas-Eugui is Legal Officer at the Trade, Environment, Climate Change and Sustainable Development Branch, DITC at UNCTAD. He was also Deputy Programmes Director at ICTSD; Senior Attorney at CIEL; Attaché for Legal Affairs at the Mission of Venezuela to the WTO and Staff Attorney at the Venezuelan Institute of Foreign Trade. He has worked as an advisor and consultant for various institutions, international and national organizations such as WTO, WHO, UNCTAD, WIPO, IDLO, EPO, GIZ, South Centre, ACP Group of Countries, ACP MTS, Enabling Environments, CUTS International, Saana Consulting, QUNO, Rockefeller Foundation, AITIC, CAF, ALIFAR, ASINFAR, Ministry of Science and Technology of Venezuela, Universidad de los Andes of Colombia and PHBL consulting.

Haifeng Wang received his $\mathrm{PhD}$ from the University of Delaware, specializing in reducing $\mathrm{CO}_{2}$ emissions from international shipping. He joined the International Council on Clean Transportation in 2010, working to calculate the cost effectiveness of energy-saving technologies in the transportation sector. Prior to the University of Delaware, Dr Wang received both Bachelor and Master degrees in Economics from Ocean University of China. He also holds an MBA degree from Darden School of Business at University of Virginia.

Peter K. Yu is a Professor of Law and Co-Director of the Center for Law and Intellectual Property at Texas A\&M University School of Law. Born and raised in Hong Kong, he most recently held the Kern Family Chair in Intellectual Property Law at Drake University Law School. He also served as Wenlan Scholar Chair Professor at Zhongnan University of Economics and Law in Wuhan, China and as a Visiting Professor of Law at the Hanken School of Economics, the University of Haifa, the University of Hong Kong and the University of Strasbourg. 


\title{
14. Climate change innovation, products and services under the GATT/WTO system
}

\author{
David A. Gantz and Padideh Ala' $i$
}

\section{INTRODUCTION AND OVERVIEW}

The original General Agreement on Tariffs and Trade (GATT) was negotiated decades before climate change was recognized as a global sustainable development challenge. During the Uruguay Round (1986-1994), the World Trade Organization (WTO) agreements were negotiated and drafted without a consideration of climate change issue in mind. In recent years WTO members have failed to reach an agreement on items that were built into the agenda of future negotiations by the Uruguay Round negotiators (such as services). Emerging issues such as the overlap between trade and climate change regrettably have not been addressed. Yet, only a multilateral agreement on climate change can minimize the 'competitiveness' concerns (to maintain profits and market shares) associated with divergent national approaches to mitigating or adapting to climate change and the consequent business migration that may flow to less restrictive jurisdictions. ${ }^{1}$

In the absence of a binding multilateral agreement, climate change measures create competitiveness problems. In view of the current lack of consensus in reaching a global agreement to replace the Kyoto Protocol (Kyoto Protocol) to the United Nations Framework Convention on Climate Change (UNFCCC), this chapter attempts to identify how the WTO rules and some selected US trade rules (and any corresponding rules in other countries) may be implicated by current and proposed policies. Such policies include carbon taxes, border tax adjustments, emission trading schemes, technical regulations aimed at promoting the use of climate friendly goods, financial mechanisms that promote climate friendly goods and technologies. Each of these policies raises compliance concerns with international trade treaties.

The UNFCCC is an international treaty with 195 Parties adopted in 1992 to limit average global temperature increase and the resulting climate change. Realizing the inadequacy of the emission reductions provisions in the Convention, countries adopted the Kyoto Protocol in 1997, which legally binds only developed countries in emission reduction targets. Since the Kyoto Protocol entered into force on 16 February 2005, the Parties to the Protocol have engaged in a series of UN negotiations to achieve more ambitious results by 2030 and agree on post-Kyoto Protocol. The negotiations resulted in the 2009 Copenhagen Accord, the 2010 Cancun Agreements, the 2011 Durban outcomes and the 2012 Doha Climate Gateway. The 2011 Durban conference agreed that all countries adopt a global legal framework covering all country parties at a climate conference in Paris in 2015. The 2013 Warsaw conference and 2014 Lima conference agreed that all countries are to put forward their proposed emissions 


\section{Research handbook on intellectual property and climate change}

reduction targets for the 2015 agreement as intended nationally determined contributions well in advance of the Paris conference. ${ }^{2}$

A universal global climate change Agreement that legally binds all country parties will likely be adopted at the Paris conference in December 2015 and implemented from $2020{ }^{3}$ This agreement will likely take the form of a protocol, another legal instrument or 'an agreed outcome with legal force'. As of February 2015, an official negotiation text for universal climate change agreement was agreed in Geneva and is being negotiated through a process known as the Durban Platform for Enhanced Action (ADP). Considering the fact that competitive concerns stem from the lack of obligation by developing countries under the current climate change agreements, a successful adoption and implementation of a universal climate change agreement applicable to all Parties would minimize these concerns.

Absent new binding climate change commitments, harmonious coexistence of trade and environmental regimes are important to ensure predictability, transparency and the fair implementation of climate friendly measures which have a trade impact. The WTO explicitly recognizes 'sustainable development' as one of the objectives of the multilateral trading system in the preamble to the Marrakesh Agreement establishing the WTO and allows its members to use trade measures to protect the environment under certain conditions. ('Sustainable development' was absent from the preamble to the GATT 1947.) Article 3.5 of the UNFCCC and Article 2.3 of the Kyoto Protocol provide that measures taken to combat climate change should not constitute a means of arbitrary or unjustifiable discrimination or a disguised restriction on international trade and should be implemented to minimize adverse trade effects. Moreover, the UNFCCC participates in meetings of the WTO Committee on Trade and Environment (CTE) and serves as ad hoc observer to the CTE overseeing the specific trade and environment negotiations (CTESS) while the WTO Secretariat attends the UNFCCC Conference of Parties meetings.

Despite the shared principles within the current trade and environment regimes, a 'collision' between trade and climate change regimes may occur when a country adopts unilateral trade measures to address climate change in the absence of an international agreement to resolve the possible conflict. Therefore, a multilateral legal framework which mutually supports trade and climate regimes needs to be established in the near future.

This chapter aims to identify some of the major sources of tension between climate change-related measures proposed or implemented on the national level and the trading rules as they have been applied by the WTO dispute settlement bodies over the past nearly 20 years. As of February 2014, almost 500 climate laws had been passed in 66 countries. ${ }^{4}$ Keeping in mind the fact that the provisions of the WTO agreements were not drafted to address climate change challenges, we need to hypothesize their application in light of the evolving WTO jurisprudence in the context of trade and environment.

As former WTO Appellate Body member, James Bacchus, observed:

There is no way of avoiding linkage between trade and climate change. Economically, environmentally, and, not least politically, they are linked inextricably. But somehow we must 
find a way to continue to lower barriers to trade while also combating climate change. We must prevent a collision between Trade and Climate Change that would be disastrous for both. $^{5}$

Careful and thoughtful analysis of the WTO rules, as well as the jurisprudence of the Appellate Body, provides hope for an appropriate balancing of environmental and 'free trade' goals. It also provides hope that the two are not inherently in opposition, but rather that compliance with one may promote the objectives of the other.

One of the most important documents on the connection of trading rules and climate change is the 2009 WTO-United Nations Environment Programme (UNEP) Report on 'Trade and Climate Change'. ${ }^{6}$ In this chapter, we have initially used the outline of that report in identifying many of the domestic measures that may be taken to combat climate change and how each will raise different issues in the context of the current trade rules and jurisprudence. These measures fall within the context of three broad categories of national approaches to climate change: (1) internalizing the environmental cost of greenhouse gas (GHG) emission through taxes and trading; (2) financial mechanisms promoting climate friendly goods, technologies and services; and (3) technical requirements to promote the use of climate friendly goods. ${ }^{7}$ We have also relied on a number of other working papers and analyses, including the work of the WTO's Trade and Environment and Technical Barriers to Trade Committees. ${ }^{8}$

We do not, however, discuss the following: any particular national climate change legislation in terms of its compatibility with WTO rules; national trade laws, except that we provide an exemplary discussion of US implementation of the WTO rules on antidumping and on countervailing duties (CVD) and certain selected US trade laws; the WTO Agreement on Trade-Related Aspects of Intellectual Property (TRIPS) (which is the subject of Chapter 4 by Daniel Gervais); and regional or bilateral trade agreements, such as the European Union (EU) and the North American Free Trade Agreement (NAFTA). ${ }^{9}$

The next section describes in more detail the three categories of national approaches to climate change, and highlights potential competitiveness concerns raised by each. The following section discusses selected WTO provisions that, in our opinion, are most likely to be used to evaluate WTO treaty-compliance of the three categories of national measures. These include an analysis of Articles of the General Agreement on Tariffs and Trade 1994 (GATT 1994), ${ }^{10}$ other Annex 1A Agreements addressing trade in goods, and a brief discussion of the General Agreement on Trade in Services (GATS). ${ }^{11}$ The final section focuses on WTO trade remedy laws, as countries may utilize these provisions and mechanisms to address competitiveness issues that will inevitably come about, such as from subsidizing green technologies. 


\section{Research handbook on intellectual property and climate change}

\section{NATIONAL APPROACHES TO COMBATING CLIMATE CHANGE AND THEIR COMPETITIVENESS IMPLICATIONS}

\section{Category A Measures: Internalizing the Environmental Cost of GHG Emissions through Taxes and Emission Trading Systems (ETS)}

Governments have pursued price and non-price mechanisms to encourage energy efficiency and to internalize the costs of GHG emissions. One approach is the imposition of a carbon or energy tax on products based on the extent of their GHG emissions during their production or the production of their component parts. ${ }^{12}$ Another approach has been to impose quantitative restrictions on GHG emissions by applying a GHG emission cap on total emissions within a sector or a country and then providing industries with 'allowances' to cover emissions up to the total cap amount. ${ }^{13}$ Such allowances can be auctioned or given away for free through an emission trading system (ETS) and can be traded in markets under various rules, including a rate-based system in which the trading rate may depend on the emitting sector (and which may not

Category A measures in the form of a carbon tax or ETS raise concerns of 'carbon leakage' because these measures are not enacted and implemented worldwide in a coherent manner. Carbon leakage is defined as the 'risk of energy intensive industries relocating to countries with weaker environmental policies'. ${ }^{15}$ International trade has been blamed for the inability of sectors or companies to remain competitive in jurisdictions with higher environmental standards, as industries flow to jurisdictions with less stringent regulatory standards. This will undermine the effectiveness of global climate change mitigation and adaptation efforts and offset GHG emissions reduced elsewhere. Governments have sought to restore some level of competitiveness by proposing border tax adjustments (BTAs) on imported goods from countries that have no or lax environmental policies with regards to GHG emissions. In view of the fact that we do not yet know what specific forms of BTAs will be put into place (particularly given the failure in 2009 to enact legislation to take actions against trading partners that fail to meet US GHG standards), ${ }^{16}$ it is difficult to analyze potential WTO violations arising from the measures. The Intergovernmental Panel on Climate Change Summary for Policymakers identified major mid-term and long-term measures to mitigate and adapt to climate change, but did not mention Border Carbon Adjustments (BCAs). ${ }^{17}$ The discussion of Articles I, II, III, X, and XI of the GATT, the Technical Barriers to Trade Agreement (TBT Agreement), and the Agreement on Subsidies and Countervailing Measures (SCM Agreement) ${ }^{18}$ will be relevant for Category A.

\section{Category B Measures: Financial Mechanisms Promoting Climate Friendly}

It is clear that climate friendly goods and technologies are not being developed as quickly as the world may require. Because technology to make renewable energy as cost-effective as fossil fuel and electricity has yet to be developed, it is arguable that government support is necessary to make renewable energy competitive (in view of research, massive production, and consumption, subsidies for fossil fuels and other 
non-renewable energy generation technologies). For example, between 2002 and 2008, the US government paid approximately $\$ 72$ billion in fossil fuel subsidies. ${ }^{19}$

The WTO-UNEP Report provides some examples of various types of government support for alternative technologies. These include:

- tax exemptions, tax credits and tax rebates on invention, deployment and increased use of such climate friendly technologies. Such tax benefits can be granted to reward either consumption or production of climate friendly goods. For example, the Chinese government provides both types of benefits, reducing the value added tax (VAT) for small hydroelectric wind and biogas power generation plants. Many countries, including Mexico, the Netherlands, India and the US, offer tax benefits through 'accelerated depreciation' that allows plants using renewable energy technologies to depreciate the value of their equipment at a faster rate, reducing the amount of tax imposed; 20

- price support measures, such as a 'feed in tariff' that regulates the minimum price guaranteed for renewable energy companies, or 'net metering', which provides consumers that supply the power grid with more energy than they use (such as through solar panels) credit on future energy bills; and

- investment support to defray the cost of installing or deploying renewable energy technologies. Investment support policies return a specified percentage of the construction or installation cost to the investor in the form of a capital grant. For example, the California Solar Initiative provides rebates to homeowners, businesses, and farmers for installing rooftop solar systems. ${ }^{21}$

The predominant trade issues in these contexts are raised under the SCM Agreement.

\section{Category C Measures: Technical Requirements to Promote the Use of Climate} Friendly Goods

Nations have also proposed technical requirements in the form of mandatory technical regulations and voluntary standards to bring about emission reductions and gains in energy efficiency. Examples include fuel economy standards for cars, eco-design requirements for energy-using products, and minimum energy efficiency performance standards for major domestic appliances. In addition, international standards that have been developed by international organizations such as the International Organization for Standardization (ISO) can be used by nations as a basis for developing their own standards. The ISO has adopted four standards (14064-1, 2 and 3:2006 and 14065: 2007) that include requirements for quantification and reporting of GHG emissions and reductions. These standards are related to conformity assessment procedures and do not include any product-specific requirements on emission levels. ${ }^{22}$

For trade purposes, technical regulations are mandatory and standards are voluntary. Both technical regulations and standards can be product-related or process-related. Product-related regulations usually focus on the environmental implications of the final product being imported, while process-related regulations are based on the manufacturing procedures of the product, regardless of the environmental impact of the final product. GATT and WTO jurisprudence distinguish between product-related process 


\section{Research handbook on intellectual property and climate change}

and production methods (PPMs) and non-product-related PPMs. ${ }^{23}$ It is arguable that technical regulations under the TBT Agreement are only applicable to processes and procedures that are related to the product; as a WTO Appellate Body decision found, 'the subject matter of a technical regulation may consist of a process or production method that is related to a product's characteristics', and a sufficient nexus to the characteristics of a product is required for the measure to be considered related to those characteristics. ${ }^{24}$ Product-related regulations and standards can be based on: (1) design or descriptive characteristics, such as specifying a particular characteristic a product must have or specific actions that must be taken in the production process; or (2) performance, such as indicating standards of performance or mandating a particular environmental outcome per unit of production. ${ }^{25}$ Design-based technical requirements include, inter alia, requiring the use of a particular quality and specification of bio-fuels or specifying the type of energy-efficient equipment that must be used in combustion facilities. Performance standards can be set in various ways. Currently implemented performance-based requirements include, for example, standards for electricity consumption of refrigerators and requirements for phasing out of incandescent light bulbs with replacement by energy-saving bulbs that meet a minimum efficiency requirement. For another example, the US has implemented the Corporate Average Fuel Economy (CAFE) Standard, which establishes performance targets for automobiles. ${ }^{26}$

Many technical regulations or standards are reflected in the form of product labels, which may be either comparative (for example, an energy-efficiency rating in comparison with other models) or commendatory (for example, an endorsement or a certification from an independent party as being energy efficient). Some form of conformity assessment is usually necessary in order to determine compliance with technical regulations or standards. The assessment may comprise several stages, including testing, inspecting, certifying and accrediting. Each of these stages, in addition to the actual regulations or standards themselves, may raise competitiveness issues and implicate compliance issues with WTO agreements.

\section{WTO AND SELECTED US TRADE LAWS}

\section{Article I:1 (Most Favored Nation, or MFN) of GATT 1994}

Article I of GATT 1994 (the MFN provision) provides:

With respect to customs duties and charges of any kind imposed on or in connection with importation or exportation or imposed on international transfer of payments for imports or exports, and with respect to the method of levying such duties and charges, and with respect to all rules and formalities in connection with exportation and importation, and with respect to all matters referred to in paragraphs 2 and 4 of Article III [internal taxes and regulations], any advantage ... to any product originating in or destined for any other country shall be accorded immediately and unconditionally to the like product originating in or destined for territories of all other contracting parties. ${ }^{27}$ 
Article I covers (1) price mechanisms, like border taxes, on imports and exports, (2) internal taxes and charges that are imposed at the border, and (3) internal rules and regulations such as technical regulations. As a result, Category A measures (price and market mechanisms) and Category $\mathrm{C}$ measures (technical requirements) can potentially violate Article I when an implementing Member country differentiates measures on importing countries depending on the amount of GHG emitted in their production of the products.

The main issue for Article I is likely to be whether or not the amount of GHG emitted in the production of a product is relevant to the determination of likeness. GATT and WTO panels have stated that product-related PPMs that alter the characteristics of the final product may be considered in determining whether two products are not 'like'; however, the Appellate Body has never made a definitive ruling on whether or not GATT Articles III and I apply to non-product-related PPMs. ${ }^{28}$ According to the two unadopted GATT Panel Reports of Tuna - Dolphin I and Tuna-Dolphin II, non-product related PPMs do not fall within the scope of GATT Articles I and III, and instead violated GATT Article XI, because Articles I and III are concerned only with regulations on 'products'. The GATT Panel determined that GATT Article II 'covers only those measures that are applied to the product as such', and that the US Marine Mammal Protection Act (MMPA) did not fall within the confines of Article III because the regulations neither directly regulated the sale of tuna under Note Ad to Article III nor possibly affected tuna as a product under Article III:4. ${ }^{29}$ The WTO Panel in US Tuna II exercised judicial economy with respect to Mexico's GATT Article I:1 and III:3 claims, examining them instead under the TBT Agreement. Although the Appellate Body overturned this exercise of judicial economy on appeal, Mexico did not ask for a completion of the analysis of the GATT claims because the Appellate Body had found the US measure to violate TBT Article 2.1. ${ }^{30}$

There have been very few non-product-related PPM cases analyzed under Article I. The earliest analysis of whether differentiating measures based on non-product-related PPMs violated Article I can be found in a GATT decision, Belgian Family Allowances, which found that a Belgian program exempting taxes on imports from countries with a similar family allowance was in violation of MFN. ${ }^{31}$ In a later WTO dispute, Indonesia - Automobiles, the panel held that the Indonesian PPM tax was in violation of Article I because the tax was based on producer characteristics and domestic content. ${ }^{32}$ In Canada - Automobiles, the WTO panel found a non-origin-neutral measure violated Article I, but it also noted that such a measure not related to the imported product itself could be valid if the measure was truly origin-neutral. ${ }^{33}$ The panel, however, rejected Japan's argument that the word 'unconditionally' in Article I:1 implies a per se violation of the article when an advantage is accorded on criteria not related to the imported product. Thus, products that are only differentiated by the method in which they are produced cannot be considered to be 'not like' and therefore fall outside the scope of Article I.

Should the process-product distinction continue in the context of climate change measures, any measure - whether taxes or regulations - that distinguishes between two products solely on the basis of the amount of energy expended or GHG emitted in the process of making that product may be deemed a violation of Article I. Under this 


\section{Research handbook on intellectual property and climate change}

scenario, the measure can survive only if it is justified as an exception under Article $\mathrm{XX}$ (as discussed below).

\section{Article II:2(a) (Schedule of Concessions) - Border Tax Adjustment (BTA)}

Article II:2(a) of the GATT 1994 can be used to implement BTAs by allowing treatment of imported products that is 'no less favourable' than domestic products under its provisions. BTAs are used to overcome the competitiveness problem created by the diversity of approaches to combating climate change, specifically, carbon leakage or the relocation of firms to jurisdictions with less rigorous environmental regulations. Government proposals for BTAs include imposing taxes (which need not occur at the border) on goods imported through foreign importers or granting tax rebates to domestic producers exporting their goods to foreign countries. ${ }^{34}$ The US has imposed environmental BTAs on imports of specified chemicals and other products to balance domestic excise taxes under the US Superfund Amendments and Reauthorization Act of 1986. In addition, BTAs were imposed to complement a US excise tax on ozone depleting commodities that took effect in 1990. However, some are skeptical about the introduction of BTAs by the EU or other developed countries in the near future..$^{35}$

Article II:2(a) provides a method of overcoming the competitiveness issue by allowing WTO members to impose a charge on imported products that is equivalent to an internal tax charged on domestic like products, as long as the internal tax is applied consistently with the national treatment (NT) requirements under Article III:2. Of course, as was mentioned in relation to Article I above and will be discussed at greater length under Article III, there is uncertainty as to whether a tax or regulation could consider two competing products as not 'like' based on GHG criteria.

Article II:2(a) allows two types of BTAs: (1) charges imposed on imported products that are 'like' domestic products; and (2) charges imposed on articles from which the imported products have been manufactured or produced in whole or in part. According to Article II:2(a) of the GATT 1994, members are permitted to impose:

[a] charge equivalent to an internal tax imposed consistently with the provisions of paragraph 2 of Article III in respect of the like domestic product or in respect of an article which the imported product has been manufactured or produced in whole or in part. ${ }^{36}$

The 1970 GATT Working Party Report on BTAs (Working Party Report) used the Organization of Economic Cooperation and Development (OECD) definition of border tax adjustment, which states that a BTA is "any fiscal measure which puts into effect, in whole or in part, the "destination principle", under which a product is taxed based on the tax system of where the products are consumed' ${ }^{37}$ The Working Party distinguished between BTAs on imports (tax on imported products corresponding to a tax borne by similar domestic products) and those on exports (refund of domestic taxes when products are exported). ${ }^{38}$

Adjustments on imports also clearly implicate Article III (national treatment), as such taxes could potentially treat imported products differently from domestically produced products. Likewise, adjustments on the export side implicate Articles I (most favored 
nation treatment) and XVI (subsidies) and the SCM Agreement, as such tax support for domestic products would constitute a subsidy to the domestic industry. ${ }^{39}$ Other articles relevant to the BTA issue include Articles VI, and VII.

The Working Party also distinguished between direct and indirect taxes, indicating that direct taxes are those imposed on producers, such as taxes on property or income, while indirect taxes are those applied to the products themselves in the form of a sales tax, excise tax or value added tax. ${ }^{40}$ (The Appellate Body has held that the US could not rebate or otherwise adjusts its direct taxes as they constituted prohibited export subsidy. ${ }^{41}$ ) At the time, most GATT members accepted as valid the distinction between $\operatorname{tax}$ adjustments on indirect taxes that were applied to the product and direct tax adjustment applied to the production process. The assumption behind this distinction is that indirect taxes are passed on to the consumers and direct taxes are not. The ineligibility of direct taxes for BTA was confirmed in 1976 in a GATT panel decision, United States - Tax Legislation (DISC) ${ }^{42}$

While it is generally agreed that a domestic carbon/energy tax constitutes an internal tax, it remains unclear whether a price paid by an industry to participate in an ETS and hold an emission allowance qualifies as an internal tax or internal charge of any kind for purposes of Article II:2(a). Under the second type of permitted BTA, the questions arise as to whether energy inputs or fossil fuel use in the production process can be considered as articles used in manufacturing or production and whether taxes or other charges that are based on non-product related PPMs may be adjusted under Article $\square: 2$ (a). Some commentators argue that there is a distinction between indirect taxes that can be adjusted at the border, such as those applied to products, and indirect taxes that cannot be so adjusted, such as those applied to processes. ${ }^{43}$ It is plausible to argue that Article II:2(a), by permitting charges on imports equivalent to an internal tax, supports the idea that BTAs may be permissible on non-incorporated PPMs (such as energy inputs). ${ }^{44}$

Even if BTAs were permissible on non-product related PPMs based on Article II:2(a), there are additional complications with using BTAs to address competitiveness issues raised by non-price regulations or standards such as emission permits. As the scope of Article II:2(a) is limited to taxes and charges, it is uncertain how proposed BTAs for non-price regulations or standards will be calculated. Because a BTA is an adjustment of the taxes imposed domestically on imported products, countries will most likely face difficulties in determining the appropriate BTA to charge for non-product related PPMs on imports that are similar to taxes on like domestic non-product related PPMs. It is very likely that difficulties in calculation of BTAs in the context of non-price related GHG measures could create problems under Article III's non-discrimination principle. ${ }^{45}$

\section{Article III}

Article III of the GATT 1994 and the interpretative note (Note Ad) to Article III incorporates the national treatment principle. The most important provisions are Article III:2 (referencing Article III:1) and Article III:4, which provide that: 


\section{Research handbook on intellectual property and climate change}

2. The products of the territory of a contracting party imported into the territory of another ... shall not be subject, directly or indirectly, to internal taxes or other internal charges or any kind in excess of those applied, directly or indirectly, to like domestic products. Moreover, no contracting party shall apply internal taxes or internal charges to [directly competitive or substitutable products in a dissimilar manner so as to afford protection to domestic production].

$\cdots$

4. The products of ... any contracting party imported into the territory of another contracting party shall be accorded treatment no less favourable than that accorded to like products of national origin in respect of all laws, regulations and requirements affecting their international sale, offering for sale, purchase, transportation, distribution or use. ${ }^{46}$

Under Article III and the Note Ad, internal taxes and charges or regulations collectively, internal measures - that are applied to domestic products can be imposed on imports at the border as long as the imported product is like the domestic product that is subject to the charge and the internal measures are not in excess of the domestic charge.

\section{Article III:2}

Under Article III:2 (first sentence), the Appellate Body has also held that no de minimis requirement exists for this provision, so that any divergence in taxes, no matter how minimal, will be deemed a violation of this provision as an automatic disruption of the competitive relationship between like domestic and imported goods. The scope of Article III:2 (first sentence) is limited, however, by the narrow application of the words 'like products,' a stricter standard than that applied under Article III:2 (second sentence), which only requires a showing that the domestic and imported product be 'directly competitive or substitutable.' For Article III:2 (second sentence), the GATT and WTO Panels and Appellate Body have held that there does exist a de minimis level of permissible differential taxation or treatment that may be product specific and depend on the extent of cross-price elasticity. Article III:2 (second sentence) also prohibits measures that are applied 'so as to afford protection' to the domestic industry. ${ }^{47}$

In Japan - Alcoholic Beverages II, the Appellate Body stated that the 'so as to afford protection' language does not refer to the 'intended objective' of the measure, but rather to whether the measure was 'applied' in a way that afforded protection, which could be discerned from the 'design, the architecture, and the revealing structure of a measure'. ${ }^{8}$ In other words, the intention or the aim of a measure is irrelevant while, at the same time, certain objective criteria, such as 'the design' of a measure, can show how an application is protective. The reality is that the Appellate Body does not want to be in a position of second-guessing a member's intention, so it will most likely always state that 'intention' is irrelevant.

\section{Article III:4}

Article III:4 applies to all measures that are not taxes or charges. In Korea-Beef, the Appellate Body found that regulatory distinction based on origin of products does not necessarily violate Article III and that, in fact, different treatment may be valid so long 
as the treatment is 'no less favorable', in other words, the treatment does not 'modif[y] the conditions of competition in a market to the detriment of imported product'. ${ }^{49}$ In Dominican Republic - Cigarettes, the Appellate Body held that 'the existence of a detrimental effect on a given imported product' does not necessarily mean a violation of less favorable treatment language, if the detrimental action was unrelated to the foreign origin of the product..$^{50}$

\section{Article III and non-product related PPMs}

Category A measures that are based on prices, such as a border tax, must be analyzed under Article $\Pi I I: 2$ and, if based on a non-price mechanism, under Article III:4. Category $\mathrm{C}$ measures can potentially fall within the scope of Article III:4. The most important issue for climate change legislation in regard to Article III is whether non-product related PPMs - such as the amount of GHG emitted in production of a product - makes such products 'not like' if they would otherwise be viewed as 'like' in regard to product related PPMs. Pursuant to GATT and WTO jurisprudence, the determination of likeness is fact specific and based on a case-by-case analysis. The criteria for determining likeness include: (1) physical characteristics; (2) end use; (3) consumer preferences (elasticity of substitution); and (4) the tariff classification applied to each product. ${ }^{51}$ The weight given to particular likeness criteria also varies depending on the product.

Earlier GATT panel decisions have held that Article III, based on its own wording, is applicable solely to products, and thus the processes by which those products are made that do not impact their physical characteristics (non-product related PPMs) do not make products unlike. ${ }^{52}$ If that analysis holds, then any measure - whether in the form of taxes, charges, or regulations and standards - that distinguishes between products based on the amount of GHG emitted in their production (non-product related PPMs) will be deemed to treat differently otherwise like products, and could thus be held in violation of Article III: 2 or Article III: 4 and thereby require justification through Article $\mathrm{XX}$ (as discussed further below).

It is important to note that in the EC - Asbestos dispute, the Appellate Body overturned the Panel's conclusion that products containing asbestos and non-asbestos material that were used for the same end-use could be considered like. ${ }^{53}$ The Appellate Body found that the existence of carcinogenic potential is sufficient to make one product unlike another, even though the non-asbestos product also contained some risk and the asbestos product could be handled with adequate precautions so as to minimize the risk. ${ }^{54}$ Because the $E C$ - Asbestos decision was discussing the physical characteristics of the product itself rather than the process by which the product was manufactured, its utility for the present purposes is limited. Nonetheless, it is significant that the Appellate Body held that health risk posed by the product at issue are clearly relevant to the question of likeness.

Because Article III has been held to apply only to products as such, non-productrelated PPMs may need to be analyzed only under Article XI (see discussion below). This is in contrast to the position of the United States that process-oriented measures should only be addressed under Article III, based on the wording in the Note Ad of Article III. ${ }^{55}$ The Note Ad states that internal measures (including taxes, charges, rules and regulations) that are applied 'at the time or point of importation, [are] nevertheless 


\section{Research handbook on intellectual property and climate change}

to be regarded as ... internal tax[es] or other internal charge[s] ... and [are] accordingly subject to the provisions of Article III'. GATT Panels objected to this either/or analysis, stating that the phrase 'subject to' does not always preclude the simultaneous application of both provisions. ${ }^{56}$

In sum, there is uncertainty about whether or not two products will be considered 'not like' solely based on non-product-related PPMs, such as the amount of GHG emissions of the production process or the GHG emissions of the constituent parts of a product. In such circumstances, violations of Article III (or Article I) would necessitate reliance on Article XX.

\section{Article XI}

Article XI:1 states:

No prohibitions or restrictions other than duties, taxes or other charges, whether made effective through quotas, import or export licenses or other measures, shall be instituted or maintained by any contracting party on the importation of any product of the territory of any other contracting party or on the exportation or sale for export of any product destined for the territory of any other contracting party.

In view of the breadth of Article XI, its prohibitions can potentially encompass all non-tariff barriers and any type of quantitative restriction, such as a cap on total emissions.

Article XI, originally adopted as part of the GATT 1947, was intended as a blanket prohibition against quotas and other forms of non-tariff barriers (including health, environmental, and product safety regulations, approvals and prohibitions) at a time when modern, complex, administrative states did not exist, particularly in developed economies. In addition, it preceded the proliferation of non-tariff barriers, including environmental regulations. As a result, Article XI has always been successfully invoked when challenging conservation or environmental measures, forcing defenders of such measures to rely on the general exception provisions of Article XX.

All climate change-related measures pertaining to products that fall into any of the three categories identified above can potentially be in violation of Article XI:1 and therefore require justification under Article XX. Because Article XI:1 is a market access provision, it is irrelevant whether the domestic industry is also subject to the same climate change-related measures, such as a carbon tax, cap on total emissions, or technical regulations or standards.

According to the Interpretative Note to Annex 1A of the WTO Agreements, to the extent that there may be a conflict between Article XI:1 of the GATT 1994 and any of the other Agreements in Annex 1A (Covered Agreements), the provision of the other Annex 1A Agreement prevails, but only to the extent of the conflict. Although, lacking a clear definition of conflict and not precluding simultaneous application, this Interpretative Note (which is not limited to Article XI:1 in its scope) is nevertheless a de facto limitation on the extreme breadth of measures implicit under the scope of 'other measures' in Article XI:1. Therefore, if a climate-related measure takes on the form of a technical regulation under Category $\mathrm{C}$, or results in the imposition of a countervailing duty, for example, to offset the amount of export credit or rebate given to a domestic 
product under a Category A BTA, the measure should be primarily analyzed under the TBT Agreement or the SCM Agreement, respectively, rather than under Article XI:1. (The obligations in the WTO Agreements are generally cumulative, can be complied with simultaneously and different provisions of a measure may be subject to different WTO obligations and sometimes even the same provision of a measure can be subject to different WTO obligations. ${ }^{57}$ ) In addition to the SCM and TBT Agreements, other WTO Agreements that may limit the application of Article XI:1 include: the Sanitary and Phytosanitary Agreement (SPS Agreement); the Agreement on Trade Related Investment Measures (TRIMs); the Agreement on Implementation of Article VI of the General Agreement on Tariffs 1994 (Anti-Dumping Code); the Agreement on Rules of Origin; and the Agreement on Import Licensing Procedures.

\section{Article $X$ and Transparency}

Transparency has long been a pillar of the multilateral trading system. Transparency provisions can be found throughout the WTO agreements and encompass all provisions requiring publication and notification of new and existing measures in a timely manner, setting out procedural and administrative procedures, requiring simplicity and harmonization of laws, and addressing application or administration of trade measures, including independent review of administrative and/or judicial determinations. ${ }^{58}$ Notwithstanding these provisions, the term 'transparency' continues to denote an opaque concept. The breadth and meaning of the word is affected by the evolving mandate of the WTO. If one views that mandate as solely to promote market access and non-discrimination, then the scope of transparency is limited to clarifying and simplifying the trading rules for market actors. If, on the other hand, the WTO also is responsible for promoting sustainable development and addressing the needs of different members at different levels of economic development, transparency in the administration of trade-related laws is an integral part of promoting good governance at the domestic level.

All climate change-related measures can be challenged on transparency grounds if the measures are applied in a manner that is unpredictable and leads to discriminatory (de facto or de jure) protectionist application. Article X of the GATT 1994 requires that all trade related measures of general application be: (1) promptly published (Article $\mathrm{X:1)}$; (2) applied only after publication (Article X:2); (3) 'administered in a uniform, impartial and reasonable manner' (Article X:3(a)); and (4) subject to some sort of independent review (Article $\mathrm{X}: 3$ (b)). Category A, B and $\mathrm{C}$ measures can all violate these broad provisions.

\section{Article $X$ and the TBT Agreement}

The relationship between Article $\mathrm{X}$ and other Covered Agreements is unclear. The Appellate Body has not been consistent in this regard. The Appellate Body has found Article $\mathrm{X}$ to be applicable simultaneously with the Import Licensing Procedures covered under the Import Licensing Agreement, but not simultaneously applicable to the Agreement on the Implementation of Article VI of GATT 1994, on the ground that antidumping measures are not measures 'of general application' under Article X:1. ${ }^{59}$ There are many transparency-related provisions throughout the WTO Agreements, 


\section{Research handbook on intellectual property and climate change}

including GATS and TRIPS, which could be raised to challenge climate-related measures. Article $\mathrm{X}$ is also relevant to the test of the Chapeau of Article XX (see discussion below).

\section{Article $\mathrm{XX}$}

Article XX, the 'General Exceptions' provision, reads in relevant part:

Subject to the requirement that such measures are not applied in a manner which would constitute a means of arbitrary or unjustifiable discrimination between countries where the same conditions prevail, or a disguised restriction on international trade, nothing in this Agreement shall be construed to prevent the adoption or enforcement by any contracting party of measures:

(b) necessary to protect human, animal or plant life or health;

.

(d) necessary to secure compliance with laws or regulations which are not inconsistent with the provisions of this Agreement, including those relating to customs enforcement, the enforcement of monopolies operated under paragraph 4 of Article II and Article XVII, the protection of patents, trade marks and copyrights, and the prevention of deceptive practices; $\cdots$

(g) relating to the conservation of exhaustible natural resources if such measures are made effective in conjunction with restrictions on domestic production or consumption.

Article $\mathrm{XX}$ also addresses a wide range of other interests, including prison labor, public morals, the sale of gold and silver, and so on.

The language of Article XX was originally proposed by the United States during the International Trade Organization (ITO) negotiations in the aftermath of World War II and is taken from the 1923 Agreement. ${ }^{60}$ Article XX not only is important in itself, but also its jurisprudence can be and has been used in connection with the TBT Agreement, which is the most relevant WTO Agreement to Category C measures. In view of the distinction between product-related PPMs and non-product related PPMs described earlier, it is likely that Category A measures in particular may need to be justified under Article XX. Article XX exceptions that are most relevant to climate change policies are Article XX(b) - necessary to protect humans' safety, health or life from the adverse consequences of climate change - and (g) - relating to the conservation of the earth's climate and certain plant and animal species that may disappear due to global warming. It is also significant that Article $\mathrm{XX}$ has been held to be applicable to provisions of the SCM Agreement, making it also relevant to Category B measures.

Under Article XX, WTO members possess a fundamental right to take measures to protect the environment at a level they consider appropriate, as well as to make relevant determinations unilaterally in certain circumstances. This orientation does not place such measures beyond legal challenge, but it certainly implies that governments are presumed to act in good faith when they adopt environment-related measures. It also goes some way in shifting the burden of proof towards the complainant in the case of a legal challenge. Nevertheless, such measures are monitored and are prohibited if considered protectionist. ${ }^{61}$ 
In order to validly justify a particular measure under Article $\mathrm{XX}$, the measure in question must first fall under and be analyzed pursuant to one of the subparagraphs. First, the aim of the measure in question is examined to ascertain whether the measure on its face supports the public policy objectives set out in that particular subparagraph, such as protection of health or conservation of an exhaustible natural resource. Should a measure be deemed to address a public policy objective recognized under a subparagraph and on its face supports that objective, the measure is then analyzed under the 'Chapeau' (preamble) of Article XX.

Article $\mathrm{XX}(\mathrm{b})$ allows for a measure to be inconsistent with other provisions of the GATT if such a measure is 'necessary' for the protection of human, animal or plant health. Under the GATT 1947, the word 'necessary' was interpreted to mean the measure that was least GATT inconsistent, that is, the least trade restrictive among all the available alternatives. This made a necessity defense virtually impossible to win, as there were always other alternatives available. The Appellate Body jurisprudence discussed below has since recognized the right of a government to select its own level of protection against health risks posed by products, even if such a right greatly restricts trade. Accordingly, the 'necessity' defense is much easier to establish under the weighing and balancing test.

In EC - Asbestos, the Panel and the Appellate Body upheld as justified under Article $\mathrm{XX}(\mathrm{b})$ a French ban on importation of asbestos and asbestos containing products. The Appellate Body stated that the permitted level of trade restrictiveness of a measure is inversely affected by the value that the public policy seeks to protect. Given the known carcinogenic qualities of asbestos, the trade restrictiveness of a complete ban was warranted: '[I]n this case, the objective pursued by the measure is the preservation of human life and health through the elimination, or reduction, of the well-known, and life-threatening, health risks posed by asbestos fibres. The value pursued is both vital and important in the highest degree.' 62

In the more recent cases, the Appellate Body has made it easier to meet the requirements of Article $\mathrm{XX}(\mathrm{b})$. In Korea - Beef, the Appellate Body set forth a three-part weighing and balancing test to determine whether a measure was 'necessary', considering: (1) the relative importance of the common interests or values that the law or regulation to be enforced are intended to protect; (2) the extent to which the measure contributes to the realization of the end pursued; and (3) the extent to which the compliance measure produces restrictive effects on international commerce, ${ }^{63}$ including the availability of other WTO-consistent alternatives that guarantee the desired level of protection.

In Brazil - Retreaded Tyres, the Appellate Body held that a measure is 'necessary' to protect human health under Article $\mathrm{XX}(\mathrm{b})$ so long as it brings about a material contribution to the achievement of a legitimate public policy. Under this reasoning, a trade restriction such as a carbon tax or green technical regulation violating specific WTO rules could be found WTO-compliant if the measure materially contributes to the reduction of GHGs and is 'not merely marginal or insignificant' in achieving that goal. In addition, the Appellate Body recognized that less trade-restrictive measure should not only be available, but must also be technically and financially realistic, taking into account the economic and development status of the Member. ${ }^{64}$ Most importantly, the 


\section{Research handbook on intellectual property and climate change}

burden of proving the existence of other less-GATT-inconsistent measures that guarantee the desired level of protection was placed on the complainant instead of on the respondent. ${ }^{65}$ This was a significant change that should greatly aid members responding to challenges to climate change-related measures under Article XX(b).

Similarly, Article $X X(\mathrm{~g})$ jurisprudence has evolved to allow for easier justification of an otherwise GATT-inconsistent measure. It is settled through GATT and WTO jurisprudence that 'relating to' conservation and 'in conjunction with' restrictions means 'primarily aimed at' preserving an exhaustible natural resource and rendering effective an existing measure. Prior to the WTO, 'primarily aimed at' was interpreted to exclude any other intermediary aim, so that conservation provisions that were not fully effective could not be considered to have conservation goals primarily in mind and thus could not be justified under subparagraph (g) ${ }^{66}$ Under the WTO, by contrast, a measure that is deemed to be a conservation measure and on its face does not discriminate could be found justified under the Chapeau of Article XX even if the measure discriminates in its application. In US - Gasoline ${ }^{67}$ and $U S-S h r i m p,{ }^{68}$ the Appellate Body stated that to meet the requirements of subparagraph (g) a measure must be: (1) 'primarily aimed at' the conservation of exhaustible natural resources; and (2) 'primarily aimed' at rendering effective restrictions on domestic consumption, such as safeguarding the competitiveness of the domestic industry that is already subject to the same conservation requirements. The Appellate Body in US - Shrimp also stated that the meaning of the subparagraph has evolved since 1947 and must be interpreted in light of the circumstances of today and in the context of the language of the Chapeau. Many conservation measures and energy related measures thus could be justified under Article $\mathrm{XX}(\mathrm{g})$ so long as they are non-discriminatory and applied in a manner that meets the requirements of the Chapeau - including good faith attempts at replacing a unilateral trade sanction with a multilateral approach.

Once a measure has been successful in fulfilling the requirements of one of the subparagraphs of Article XX, it then must also fulfil the requirements of the Chapeau of Article XX. The Chapeau of Article XX states that such a public policy exception should not be applied in a manner that constitutes either a means of arbitrary or unjustifiable discrimination between countries where the same conditions prevail or a disguised restriction on international trade. The Appellate Body has held that for a measure to survive scrutiny under the Chapeau, it must be applied in such manner that any resulting discrimination not be deemed 'arbitrary' or 'unjustifiable'. ${ }^{69}$ The Appellate Body will look favorably at measures, so long as attempts by the respondent country at multilateral negotiations seem to be taking place in good faith and in a consistent manner. ${ }^{70}$ The key issue here is the extent to which a consensus exists that the product either needs to be regulated to protect health or the environment or is an exhaustible natural resource meriting its restriction in trade.

According to Article XX jurisprudence, the greater the consensus that exists among WTO members regarding the types of domestic restrictions needed to address climate change, the more likely measures conforming to such restrictions will survive scrutiny under the Chapeau. The Appellate Body may be reluctant to tackle the difficult issue of balancing the environmental objective of reducing GHG emissions against its trade consequences, as would be required under the 'arbitrary and unjustifiable' requirement of the Chapeau. ${ }^{71}$ For example, in EC-Beef Hormones, the Panel and the Appellate 
Body did not analyze the EC's measures of banning imported meat and meat products treated with hormone injections under Article XX. Instead, the Appellate Body affirmed the decision of the Panel that the EC did not adequately assess the risks of hormone injections and was therefore in violation of Articles 5.1 and 5.2 of the SPS Agreement. By avoiding analyzing the EC's measure under one of Article XX's subparagraphs, both dispute bodies also avoided analyzing the measures under the Chapeau of Article $\mathrm{XX}$ and did not have to partake in a balancing test between the EC's regulatory policy and its trade consequences. The Appellate Body is likely to be hesitant to review domestic climate change legislation and to balance interests without any agreement or guidance from the Members, but it may ultimately be forced to do so.

In US - Shrimp, the Appellate Body found that the application of a US measure aimed at conserving sea turtles caught in shrimp nets was initially too 'rigid and unbending' because it required other countries to adopt a regulatory program that was 'not merely comparable but rather essentially the same as that applied to United States shrimp trawl vessels'. However, the Appellate Body found that the measure was brought into compliance with Article XX with minor adjustments that introduced some flexibility against the backdrop of good-faith (albeit unsuccessful) negotiations for a multilateral agreement. A unilateral measure addressing climate change thus theoretically could be justified through the Chapeau in the absence of multilateral or regional consensus. $^{72}$

To survive analysis under the Chapeau, such national measures must be moving towards a harmonization of national approaches and, eventually, a multilateral agreement. In the context of domestic climate change legislation, an otherwise WTOinconsistent measure must demonstrate comparable effectiveness to less-inconsistent alternatives given the different costs associated with the vast diversity of GHG-related measures, including measures that are sectoral as opposed to national in scope. In addition, the country adopting the measure unilaterally must fulfill the requirement for a good-faith attempt at multilateral solution.

An additional issue that members will face in addressing climate change measures is the need to take into account the development angle and the special and differential obligations and liabilities of WTO Members. The WTO agreements recognize special and differential treatment for developing countries. The Chapeau of Article XX also requires non-discriminatory treatment only 'among countries where the same conditions prevail'. In the climate change context, this special and differential treatment is also found in the 'common but differentiated responsibilities' language of UNFCCC and reflected in the differential obligations to reduce GHG emissions under the Kyoto Protocol (a topic discussed in Chapters 3, 4, 5 and 6 by Sanford Gaines, Daniel Gervais, Carlos Correa and Peter Drahos respectively) ${ }^{73}$

\section{Agreement on Technical Barriers to Trade (TBT Agreement)}

The TBT Agreement gives Members the right to adopt technical regulations and/or standards to achieve legitimate objectives, including protection of the environment, so long as they are consistent with the provisions of that Agreement. The scope of the TBT Agreement extends to all technical regulations, standards and conformity assessment procedures that apply to trade in goods, with the exception of such regulations or 


\section{Research handbook on intellectual property and climate change}

standards that fall within the scope of the SPS Agreement or the Agreement on Government Procurement (GPA, which is discussed in Chapter 15 by Denis Barbosa and Charlene de Avila Plaza). Of course, technical measures that relate to services fall under the GATS (see below).

The TBT Agreement, Annex 1, Article 1 defines a 'technical regulation' as a '[d]ocument which lays down product characteristics or their related processes and production methods, including the applicable administrative provisions, with which compliance is mandatory. It may also include or deal exclusively with terminology, symbols, packaging, marking or labelling requirements as they apply to a product, process or production method'. The TBT Agreement, Annex 1, Article 2 defines a 'technical standard' as a '[d]ocument approved by a recognized body, that provides, for common and repeated use, rules, guidelines or characteristics for products or related processes and production methods, with which compliance is not mandatory. It may also include or deal exclusively with terminology, symbols, packaging, marking or labelling requirements as they apply to a product, process or production method'. The TBT Agreement applies to the preparation, adoption and application of technical regulations and regulations by governments and standards bodies, and to conformity assessment procedures used to determine whether the relevant requirements in technical regulations or standards are fulfilled.

Under the TBT Agreement, Annex 1, a technical regulation is a mandatory measure, while compliance with a standard is voluntary (standards issues are addressed in Chapter 21 by Jorge Contreras.) The Appellate Body in EC - Asbestos and EC Sardines has elaborated the criteria for what would constitute a 'technical regulation' under the TBT Agreement. ${ }^{74}$ The document must apply to an identifiable product or group of products, although the identification need not be explicit. The document also must lay down one or more product 'characteristics', which include not only features and qualities intrinsic to the product itself but also related features such as the means of identification, presentation and appearance of the product. Finally, compliance must be mandatory. Many Category $\mathrm{C}$ measures are voluntary and thus may not fall under the TBT Agreement as technical regulations.

The definition of technical regulation also raises the question of the applicability of the TBT Agreement to non-product related PPMs. Documents would need to specify PPMs that are 'related to the product characteristic' in order to qualify as a technical regulation. The second sentence of the definition leaves room for interpretation that non-product related PPMs could be subject to labeling requirements. This view is based on the absence of the word 'related' in the second sentence of the definition of a technical regulation, which reads that technical regulations and standards 'may also include or deal exclusively with terminology, symbols, packaging, marking or labeling requirements as they apply to a product, process or production method'. The absence of the word 'related' has led some to argue that labeling of non-product related PPMs is covered by the TBT Agreement, while other regulations pertaining to non-product related PPMs are not.

Assuming that a technical regulation falls within the scope of the TBT Agreement, Articles 2.1 and 2.2 provide that the regulation must not discriminate in violation of Most Favored Nation or National Treatment obligations and must not be 'more trade restrictive than necessary to fulfill a legitimate objective such as, inter alia, national 
security requirements; the prevention of deceptive practices; protection of human health or safety, animal or plant life or health, or the environment'. In order to determine whether a measure is more restrictive than necessary, we must turn to Article XX jurisprudence and its test of necessity for guidance, while recognizing that the TBT Agreement shifts the burden of proof to the complainant - contrary to Article XX, which, as an exception, usually places the burden on the respondent.

To recall, the Article XX test of necessity considers: (1) the importance of the interests or values protected; (2) the contribution to achieving the end; and (3) the extent of restriction on commerce. ${ }^{75}$ Similarly, a TBT measure must be assessed in terms of: (1) the importance of the objective and the risks of not meeting it; (2) the effectiveness of the proposed regulation in achieving that objective; and (3) the existence and effectiveness of less trade restrictive alternatives. Jurisprudence relating to GATT Article $\mathrm{XX}(\mathrm{b})$ is relevant to the interpretation of the 'more trade-restrictive than necessary' standard in TBT Article 2.2. ${ }^{76}$

In the context of climate change, the principle issues will concern: (1) the importance of the goal of combating climate change (and/or achieving sustainable development through or while mitigating climate change); (2) the degree to which the measure makes a 'meaningful contribution' to the public policy goal identified, taking into account the different development needs of each Member; and (3) whether there are other less trade restrictive alternatives that would be as effective in achieving the stated objective. Aside from the product/process distinction discussed above, the effectiveness prong of the necessity test poses perhaps the second most daunting challenge with climate change-related technical regulation: how does one determine comparative 'effectiveness', and is this determination made on the basis of the entire economy or each sector?

Like the interpretation given to the Chapeau of Article XX, the TBT Agreement explicitly prefers a multilateral approach and pushes for adoption of international standards and harmonization of domestic variants of standards. ${ }^{77}$ Specifically, the TBT Agreement provides that if a technical regulation is consistent with an international standard, it is presumed to be compatible with the requirements of the TBT Agreement. ${ }^{78}$ But there is no definition of what constitutes an international standard or consistency with it. In EC - Sardines, the Appellate Body agreed with the panel that standards not adopted by a consensus of nations qualify as relevant international standards. ${ }^{79}$ One commentator has noted that this means that 'a subgroup of WTO membership could arguably develop climate change related international standards' which would benefit from the WTO 'presumption of compatibility even if cumulative operation of the multitude of standards would not be environmentally effective, or appropriate in terms of development objectives of developing countries' ${ }^{80}$

The TBT Agreement does not require domestic compliance with international (voluntary) standards. Rather, the TBT Agreement requires that Members take reasonable measures to ensure standardization authorities within their territories respect certain disciplines set forth in Annex 3 to the TBT Agreement, which is titled the Code and Good Practice for the Preparation, Adoption and Application of Standards (Code). Under paragraph (b) of Annex 3, the Code is open to acceptance by private entities, that is, 'any non-governmental regional standardizing body one or more members of which are situated within the territory of a Member of the WTO'. If a private entity accepts 


\section{Research handbook on intellectual property and climate change}

provisions of the Code, this could lead to the creation of standards by a nongovernmental organization, including use of private labeling under paragraphs (d) to (l) of TBT Annex $3 .^{81}$

\section{Agreement on Trade Related Investment Measures (TRIMS)}

The TRIMs Agreement, despite its name, has only very limited coverage of investment issues. It effectively restricts only performance requirements (in its Annex) - such as requirements regarding how services are to be conducted, for example domestic content or national labor requirements. TRIMS imposes certain transparency obligations on national regulation of investments, restating the obligations under Article III (nondiscrimination) and Article XI (prohibition of quantitative restraints) of the GATT. TRIMS does not generally apply to government procurement of goods and services, which is separately addressed by the plurilateral GPA. ${ }^{82}$ The GPA is separately administered and includes approximately 40 WTO Members, including the EU nations, the United States, Canada, Japan and South Korea but not China or India. ${ }^{83}$ After years of negotiations from 1996 to 2011, the outcome led to an adoption of a revised GPA in March 2012. Two-thirds of the GPA parties completed their domestic ratification procedures, and the revised GPA accordingly entered into force on 6 April 2014. ${ }^{84}$

Specifically, the TRIMS Agreement prohibits requirements to 'obtain an advantage' through 'the purchase or use by an enterprise of products of domestic origin or from any domestic source, whether specified in terms of particular products, in terms of volume or value of products, or in terms of a proportion of volume or value of its local production' ${ }^{85}$ Such domestic purchase requirements were the subject of a successful WTO challenge in Indonesia - Autos. ${ }^{86}$

TRIMS was viewed by the United States and some other countries as a first step toward the WTO's coverage of investments. However, it is unlikely that the WTO will incorporate a comprehensive investment-protection agreement soon, given the opposition of many WTO members to efforts of the EU and Japan in the early 2000s and the failure to achieve a Multilateral Agreement on Investment in 1998 under the auspices of the OECD. ${ }^{87}$

TRIMS is likely to have significant relevance to trade in alternative energy products. In a September 2010 action of the United Steelworkers under Section 301 of the U.S. Trade Act of 1974 (discussed in more detail below), China and other countries were accused of providing subsidies to the wind power industry, imposing domestic content requirements for various joint venture agreements with Chinese and other countries' state-owned enterprises, and of adopting onerous technology transfer requirements and local content requirements for alternative energy goods production. ${ }^{88}$ The US initiated consultations as a result of the petition and ultimately reached a settlement under which China would eliminate a program that provided subsidies to domestic producers of wind power equipment, with a primary focus on domestic content requirements that the United States claimed were inconsistent with Article 3.1(b) of the SCM Agreement. ${ }^{89}$ Whether other WTO Members will encourage the development of indigenous clean energy sectors by enacting similar restrictions remains to be demonstrated. 


\section{General Agreement on Trade in Services (GATS)}

The GATS entered into force in January 1995 as one of the landmark achievements of the Uruguay Round. ${ }^{90}$ It is the first multilateral, legally enforceable agreement dealing with trade and investment in services. Services include any service in any sector except those supplied in the exercise of governmental functions. The GATS contains a set of provisions for general concepts, which apply to all measures affecting trade in services, and specific negotiated obligations, which apply to those service sectors and subsectors that are listed in a Member country's schedule. ${ }^{91}$ Each Member country has a list of specific commitments. The specific commitments are scheduled by modes of supply and apply only to listed service sectors and subsectors. Like the GATT, the GATS also contains an unconditional MFN clause which requires that each service or service supplier from a Member must be treated no less favorably than any other foreign service or service supplier. ${ }^{92}$

The GATS Article XIV(b) should cover environmental issues, as it relates to 'any environmental measures that members would apply to services trade for environmental purposes' ${ }^{93}$ To date, however, the GATS has not played an integral role in liberalizing environmental services. Many regard the current GATS classification as outdated. As a supplement to the GATS, the WTO has published a list known as the W/120, which classifies services into categories. As it stands, the environmental services category is sixth on this list. ${ }^{94}$ The classification focuses on the final product of environmental services and does not address the more relevant services that deal with measures preventing and reducing environmental harm. These services focus on improving the performance of developed facilities and infrastructure, as opposed to design measures, research and development $(R \& D)$ and services necessary to upgrade systems. Further, the classification looks at what is supplied to the general community and not at what the relevant industries are receiving. Finally, there is little in the GATS on private sector involvement as the classification was created at a time when governments were the predominant actors in the field. ${ }^{95}$

Because the classification is not defined clearly, confusion exists in determining whether a measure should be considered to apply to an environmental good or service. Environmental suppliers may integrate their services with an environmental good and this can complicate whether the product will fall under the GATS or the GATT. An example of this is energy-related services that involve transport, transmission and distribution. Energy related services, while termed 'services', can be seen as economic activities constituting both goods and services. ${ }^{96}$ Thus, there is a concern and growing necessity to revisit the classification system provided by the GATS.

The GATS also includes regulations relating to international trade in financial services. ${ }^{97}$ This is one of the ways the GATS has proved relevant and effective for climate change issues. The financial sectors have been growing at an alarming rate due to technological progress in communication, a widespread escalation in electronic data processing and the utility of the Internet for financial services. ${ }^{98}$ The intersection between financial services and climate change, while not intuitive, is apparent in energy-related services. Since the GATS incorporates an outdated system of classification, energy-related services can fall under the Financial Services Annex to the GATS, specifically under paragraph 5 (a) as 'any service of a financial nature'. .99 


\section{Research handbook on intellectual property and climate change}

An example of an energy related service largely used in relation to the GATS is trade in Renewable Energy Certificates (REC). ${ }^{100}$ The functioning of a REC requires a basic understanding of the production of renewable energy. Renewable energy production can be separated into two parts - the electricity or electrical energy produced by a renewable generator and the renewable 'attributes' of that generation (such as greenhouse gas emissions). These renewable attributes are sold separately as RECs, whereby one REC is issued for each megawatt-hour (MWh) unit of renewable electricity produced. When a person buys an REC, he or she is buying the renewable attributes of those specific units of renewable energy. This mechanism helps to offset conventional electricity generation in the region where the renewable energy generator is located. Trade in RECs is a market-based scheme that promotes energy production from renewable energy sources (RES).

Given the complicated nature of RECs, the trade of RECs is arguably neither goods nor services. Instead, the trade involves a series of financial transactions between financial institutions, including clearing and settlement, and thus is regulated under the GATS. Trading in RECs would also fall under entry number 7 of the $W / 120$, while also being part of the Financial Services Annex. ${ }^{101}$ While RECs are just one example of energy-related services that can fall under the provisions of the GATS, it is likely that more liberalization efforts in the energy sector will create a more important role for the GATS in climate change.

\section{Environmental Goods and Services Agreement (EGA)}

The idea of eliminating or greatly reducing tariffs on environmental goods and services is not new. Negotiating such an agreement was contemplated in the Doha Ministerial Declaration of November 2001, although the commitment was extremely weak: to conduct 'negotiations, without prejudicing their outcome, on ... the reduction or, as appropriate, elimination of tariff and non-tariff barriers to environmental goods and services'. ${ }^{102}$ However, as with most other elements of the Doha Round negotiations, no progress has been made toward such a multilateral WTO agreement. As a result, some 44 WTO Members (including the 28 members of the European Union), representing some 90 percent of global trade in environmental goods, decided in 2013 to attempt to negotiate a plurilateral EGA. As of May 2015 seven negotiating sessions had been held, with discussions focusing on the 600 products that had been nominated for inclusion. ${ }^{103}$

Separately, the Asia Pacific Economic Cooperation forum (APEC) has committed to an agreement to be concluded no later than 2015 that would reduce tariffs on a shorter list of 54 environmental goods such as waste water purifying equipment, solar panels and wind turbines, to a lever of no more than 5 percent. Some 70 percent of the affected goods "produce renewable energy, are used for environmental monitoring, analysis and assessment or are used to strengthen air pollution controls'. ${ }^{104}$

It is worth keeping in mind that regardless of making an EGA function well whether concluded as a WTO plurilateral agreement, an APEC agreement, or both challenges will remain to increasing trade in environmental goods. Windmills and solar panels are particularly susceptible to subsidies, since with relatively low fossil fuel costs such alternative methods of producing electrical energy are not cost effective. ${ }^{105}$ As discussed later in this chapter, such trade is subject to 'unfair' trade remedies, 
including anti-dumping and countervailing duty actions, and several countries, including the European Union and the United States, have imposed penalty duties on imports of Chinese windmill towers and solar panels as a result, at levels in most cases far exceeding 5 percent.

\section{WTO AND NATIONAL TRADE REMEDY LAWS}

In this section, we discuss the three World Trade Organization (WTO) authorized trade remedies (antidumping, subsidies and safeguards - as implemented in the United States ${ }^{106}$ ), and two specific trade laws of the United States (Section 337 of the Tariff Act of 1930 and Section 301 of the Trade Act of 1974). Three of these five topics (subsidies, Section 337 actions, and Section 301 actions) have particular relevance to trade in alternative energy and other 'green' products that incorporate intellectual property which may be protected by patent, trademark, copyright and other intellectual property laws at the national and global levels. Although the focus is on US laws, the points are exemplary and similar provisions may exist in other countries' laws.

R\&D subsidies are some of the most popular subsidies among WTO Members who are at the forefront of climate change-related technology development, such as China, South Korea and the United States (as discussed in Chapter 16 on patent law by Joshua Sarnoff). Some R\&D subsidies may, but many will not necessarily, be actionable under WTO rules in the absence of a comprehensive international agreement authorizing (or prohibiting) such subsidies. For example, China has announced programs to provide public investment in clean-energy technology (including but not limited to $R \& D$ ) in the $\$ 400$ billion range over the period 2006-2013; the United States announced approximately $\$ 150$ billion in subsidies, Japan in excess of $\$ 50$ billion, and South Korea more than $\$ 30$ billion. ${ }^{107}$

Section 337 and Section 301, while broader in scope, have been used in recent years to address intellectual property (for imports in regard to Section 337 for intellectual property violations and for failure by foreign nations to comply with international TRIPS rules in the case of Section 301 and related provisions). They also have been used to address various types of foreign government subsidies and other alleged violations of international trade agreements (multilateral and bilateral). The US antidumping and safeguards laws make no exception for trade in 'green' technology products.

If a comprehensive global climate change agreement were to be concluded in the next few years, including bright line rules that authorize subsidies and restrict challenges to technology transfers, the risks of multiple trade remedy actions would likely be reduced. Similarly an agreement within the WTO's Doha Round (which currently seems inconceivable) on reducing or eliminating tariffs and non-tariff barriers on environmental goods and services may decrease the number of trade remedy actions in the future. ${ }^{108}$ However, neither understanding is likely to prevent the use of trade remedies when the WTO Members or any of their major constituencies - including domestic producers, domestic intellectual property rights holders and organized labor groups - believe that protecting their markets is in the national (or their parochial) interest and unilateral action of a country is at least arguably consistent with WTO 


\section{Research handbook on intellectual property and climate change}

rules. Even a future agreement to reinstate the expired 'green light' exemption for certain $R \& D$ and environmental cleanup subsidies (discussed below) would not eliminate the possibility of the use of domestic trade remedies.

In the absence of broad agreement on restricting greenhouse gases, US and EU worker groups may from time to time be at odds with US and EU intellectual property rights holders and developers. The dominant production model may well be one in which US, EU, or other developed countries' intellectual property owners manufacture green energy goods in China, Vietnam, India or other developing countries, depriving or appearing to deprive domestic workers of manufacturing jobs in such products. Offshore manufacturing firms typically cannot join in trade remedy actions, except in circumstances where their intellectual property rights are being violated. However, remaining domestic manufacturing enterprises that are adversely affected by the foreign production may well partner with domestic labor unions in bringing antidumping and CVD actions, among others.

It is worth noting that under most trade laws in the US, the executive branch has relatively little discretion to initiate actions and to apply penalty duties if petitions for action meet all of the legal requirements (presidential discretion is considerably broader with safeguards and Section 301 actions). ${ }^{109}$ From the point of view of domestic producers or rights holders, this limited agency discretion means that if the statutory requirements for protection are met, the claimants can be reasonably sure that the anticipated protection will be implemented.

\section{Antidumping Actions: WTO and National Laws}

Antidumping measures are by far the most common of all unfair trade actions. At least 113 of 162 WTO Members have antidumping laws. During the period 1995 through 2013, some 4,519 antidumping cases were initiated. The major users of these laws (based on cases notified to the WTO) include India, the United States, the EC, Brazil, Argentina, Australia, South Africa, China, Canada, Turkey, Korea, Mexico and
Indonesia. ${ }^{110}$

GATT permits Members to impose antidumping duties (as distinct from CVDs) on imports from foreign producers.

The contracting parties recognize that dumping, by which products of one country are introduced into the commerce of another country at less than the normal value of the products, is to be condemned if it causes or threatens material injury to an established industry in the territory of a contracting party or materially retards the establishment of a domestic industry. ${ }^{111}$

The WTO Antidumping Agreement (ADA), ${ }^{112}$ US antidumping law, and the antidumping laws of many other nations provide relief against price discrimination between the domestic market and the producer's home market, regardless of the possible benefit to consumers or of economic rationality. For example, dumping laws do not seek to deal solely or primarily with predatory pricing, which refers to anti-competitive activities taken by a company that is dominant in the market so as to protect its market share from new or existing competitors. Rather, dumping laws focus on price discrimination itself, not the effects of such practices. 
While the antidumping laws do not specifically address intellectual property or climate change, they can and likely will be used against imports of alternative energy or other 'green' products that cause material injury, such as windmill generators, photovoltaic cell panels and non-incandescent light bulbs. Whether dumped alternative energy products also violate WTO constraints against subsidies or those protecting intellectual property is largely irrelevant for purposes of the dumping laws, except to the extent that antidumping duties and CVDs overlap. The GATT 1994, Article VI:5 provides that Members may not assess 'both anti-dumping and countervailing duties to compensate for the same situation of dumping or export subsidization'. This prohibition against double-counting has been confirmed by the Appellate Body. ${ }^{113}$ Of course, in source countries where goods are produced in violation of WTO subsidy or intellectual property requirements, the prices are likely to be lower in the source country if the savings are passed on to consumers and thus are less likely to result in dumping (where the comparison is typically between the home market price and the export price).

Article 2 of the ADA provides detailed guidance for the price comparisons that ultimately determine the existence of dumping. Specifically, Article 2.1 sets out the manner to determine the 'normal value' (home market selling prices, or if those do not permit a proper comparison, third country prices or a value 'constructed' from cost data). Efforts must be made to compare 'like' products, in a manner roughly similar to the 'like product' comparison in GATT Articles I and III, although the products do not have to be identical. For example it is acceptable to compare two somewhat different models of a 13-inch television with adjustments for minor differences in manufacturing costs. But it is not appropriate to compare a 20-inch television sold in the home market with a 13-inch television sold in the export market, because 20-inch and 13-inch televisions are not 'like products'.

Under Article 2.4, a key in dumping calculations is the requirement of a 'fair comparison' between normal value and the export price for the 'like product' in the domestic and export markets. If the difference between normal value and the export price is greater than zero, the difference is the dumping margin and that margin determines the amount of antidumping duties. However, differences that are less than 2 percent of the export price are considered de minimis and are not actionable in accordance with Article 5.8. In addition, under Articles 5 and 6, investigations must be conducted in a reasonably transparent manner, giving foreign producers an opportunity to participate fairly and be heard. Notwithstanding the greater degree of procedural fairness under the ADA compared to the 1979 Antidumping Code, the computations are complex and the investigating authorities tend to favor domestic interests. About two-thirds of the time in the US and with other WTO Members' investigating agencies, the result is a finding of dumping and imposition of antidumping measures, which usually are higher duties designed to offset the differential between the lower export price and the higher 'normal value'. ${ }^{114}$

Essentially, the required calculations adjust both the normal value (typically the adjusted selling price in the home market) and the export price to achieve comparable prices, through subtractions or additions for differences in selling expenses, transportation, physical characteristics, and other factors 'affecting price comparability'. The 


\section{Research handbook on intellectual property and climate change}

types of adjustments usually made to normal value include differences in 'circumstances of sale' (advertising costs, warranty costs, credit costs, and so on), differences in the merchandise, differences in freight costs and differences in the level of trade (sales to wholesalers or sales to dealers).

Under WTO law, for both antidumping and CVD investigations, the administering authority may not initiate investigations unless or until the authority has ascertained that the petition has been made 'by or on behalf of the domestic industry'.115 It is possible but highly unusual for the authority to act on its own initiative. Moreover, the application shall be considered to have been made 'by or on behalf of the domestic industry' if it is supported by those domestic producers whose collective output constitutes more than 50 percent of the total production of the like product produced by that portion of the domestic industry expressing either support for or opposition to the application. However, no investigation shall be initiated when domestic producers expressly supporting the application account for less than 25 percent of total production of the like product produced by the domestic industry. ${ }^{16}$ Of course, if some US manufacturers of the 'like product' remain in the United States, they will constitute the 'domestic industry' and can jointly support an antidumping action, alone or with their unions. In this respect, it is notable that the US Section 301 petition filed by the Steelworkers Union in September 2010 alleging among other WTO violations that China is providing WTO-illegal green technologies subsidies could not have been brought under the CVD laws because it was supported only by unions and not by any domestic producers. ${ }^{117}$

Importantly for those who believe that China will likely be the world's most significant exporter of alternative energy products, antidumping calculations for nonmarket economies (NMEs) are computed differently from those affecting market economies. US law defines an NME as 'any foreign country that the administering authority determines does not operate on market principles of cost or pricing structures, so that sales of merchandise in such country do not reflect the fair value of the merchandise'. ${ }^{118}$ Under the statute, the Commerce Department considers the following six factors in deciding whether a country should be treated as an NME country:

(1) the extent to which the currency is convertible;

(2) the extent to which wage rates are determined by free bargaining between labor and management;

(3) the extent to which joint ventures or other investments by foreign firms are permitted;

(4) the extent of government ownership or control of the means of production;

(5) the extent of government control over allocation of resources and the pricing and output decisions of enterprises; and

(6) such other factors that the Commerce Department considers appropriate. ${ }^{19}$

Based on concessions in the WTO Accession Agreements made by China and Vietnam, ${ }^{120}$ the United States, EU and Mexican authorities, among others, decline to calculate normal value based on selling prices on the grounds that those prices and related selling costs are not determined by market factors, but by central planning. Under such circumstances, the US Department of Commerce looks instead to a 
'surrogate' country at a similar level of economic development such as India or Bangladesh or Indonesia, where Commerce believes production and selling costs are determined by market forces. The labor, materials and other factor costs associated with the production and sale of the same or similar products in those countries are effectively substituted in making normal value calculations. The NME treatment provides national administering authorities with broad discretion in conducting antidumping investigations, which frequently results in finding large antidumping margins that can significantly restrict imports from NMEs such as China. ${ }^{121}$

\title{
2. Subsidies and Countervailing Duties: WTO and National Laws
}

Potentially, one of the most effective set of trade remedies in protecting domestic producers from alternative energy and other 'green' goods imports may well be those covered by Articles VI(3) and XVI of the GATT, the WTO's Agreement on Subsidies and Countervailing Measures (SCM Agreement) and national laws enacted under the authority of the SCM Agreement. The SCM Agreement provides several key mechanisms for acting against foreign government subsidies that potentially distort trade, including subsidies relating to research and development, now relatively common among WTO Members such as the United States, South Korea and China. The SCM Agreement provides for parallel remedies: government-to-government actions brought in the WTO's Dispute Settlement Body (DSB) and CVD actions brought by domestic producers under national laws.

Under Article VI:3 of the GATT 1994, WTO Members may impose CVDs but only under certain conditions:

\begin{abstract}
No countervailing duty shall be levied on any product of the territory of any contracting party imported into the territory of another contracting party in excess of an amount equal to the estimated bounty or subsidy determined to have been granted, directly or indirectly, on the manufacture, production or export of such product in the country of origin or exportation, including any special subsidy to the transportation of a particular product. The term 'countervailing duty' shall be understood to mean a special duty levied for the purpose of offsetting any bounty or subsidy bestowed, directly, or indirectly, upon the manufacture, production or export of any merchandise.
\end{abstract}

\section{SCM Agreement subsidy categories}

Under the SCM Agreement, all subsidies are effectively defined by Article 1. Two of the subsidy categories - export and import substitution subsidies and non-actionable subsidies - are treated specifically and discussed below. In general, a subsidy is deemed to exist if there is a 'financial contribution by a government or other public body' where, inter alia, 'a government practice involves a direct transfer of funds (e.g., grants, loans or equity infusion) ... [and] a benefit is thereby conferred' ${ }^{122} \mathrm{~A}$ financial contribution by a government or public body typically involves: (1) a direct transfer of funds; (2) the foregoing of government revenue; (3) the provision of goods or services other than general infrastructure; or (4) payments made to a funding mechanism including a private body - to undertake actions within (1), (2), or (3) above, provided that a benefit is conferred on the recipient company. ${ }^{123}$ However, a subsidy is not actionable under a Member country's CVD laws unless it is 'specific', in that the 


\section{Research handbook on intellectual property and climate change}

subsidy program is limited to 'an enterprise or industry or group of enterprises or industries ...' rather than made generally available. ${ }^{124}$ The specificity criterion will make many programs designed to encourage both $R \& D$ and production of 'green' goods vulnerable to remedial actions because many are targeted at specific industries rather than made generally available to business as a whole. As each case is judged on its own facts, the term 'Yellow Light' subsidy is used.

The first of the separately treated subsidy categories is export and import substitution subsidies (commonly referred to as 'Red Light' subsidies), which are prohibited under Articles 3 and 4, respectively. Such subsidies may be, for example, conditioned on the use of domestic rather than imported materials. The second subset includes certain subsidies for R\&D, environmental cleanup and disadvantaged regions (commonly referred to as 'Green Light' subsidies), which are non-actionable under Article 8. ${ }^{125}$ However, R\&D subsidies are no longer protected from evaluation under Article 8; the legal requirement in the SCM Agreement that such subsidies be treated as excluded expired on 1 January $2000 .^{126}$ US law has similarly eliminated that exception. ${ }^{127}$

Under current WTO law, such subsidies are treated as yellow light subsidies. However the green light status of R\&D subsidies may not be dead, as they may be reinstated if and when the Doha Round of negotiations is resurrected. Also, despite the expiration of the green light subsidies in 2000, the Ministers agreed in the Doha Declaration to take note of the proposal to treat as non-actionable subsidies measures implemented by developing countries with a view to achieving legitimate development goals, such as regional growth, technology research and development funding, production diversification, and development and implementation of environmentally sound methods of production. During the course of the negotiations, Members are urged to exercise due restraint with respect to challenging such measures. ${ }^{128}$ Although the Doha Declaration is not legally binding on Members, no R\&D subsidies meeting the specified requirements have been subject to a WTO challenge since 2000 .

Export subsidies are easier to challenge than other subsidies under the SCM Agreement because there is no requirement of showing 'adverse effects' as in the case of other actionable subsidies. ${ }^{129}$ However, it may be difficult to demonstrate that subsidies for the development and production of 'green' goods are export subsidies because most governments support the development and production of such goods whether the goods are for domestic consumption or export. In other words, such subsidies may not obviously be 'contingent in law or in fact ... on export performance'. Still, the Appellate Body has suggested that if new subsidies increase future production, and the ratio of export sales to domestic sales for the additional production increases, say from $2: 3$ to $3: 2$ for the additional production, this could be considered export subsidization even though much of the additional (subsidized production) is for domestic use. ${ }^{130}$ Should export subsidies be afforded to 'green' goods, they would be subject to action in the WTO and under national CVD laws.

From the perspective of governments subsidizing R\&D and 'green' goods production, the expiration of the exception for 'green-light' subsidies is unfortunate in terms of encouraging trade in alternative energy goods. Many R\&D and environmental cleanup subsidies might have fallen within the green light criteria. For example, R\&D subsidies were exempt when most of the R\&D costs of the eligible projects were covered by private investors rather than the government, and because the assistance was 
limited to support for personnel, equipment, consultancy services, overhead and other running costs permitted of those non-actionable $R \& D$ subsidies or because the goods are designed to reduce emissions for existing production facilities. ${ }^{131}$

\section{Remedies - WTO level}

The SCM Agreement contemplates two parallel means for dealing with illegal subsidies. First, private parties in a Member nation may bring CVD actions under domestic law, resulting in the imposition of offsetting or countervailing duties. The procedural and legal requirements are similar to ADA actions addressed earlier (including the material injury requirement). ${ }^{132}$ However, there is a second alternative without any parallel in the ADA. A Member government may also seek redress through the DSB. If the action is against prohibited export subsidies, it is sufficient to show the existence of the subsidy without any demonstration of injury. ${ }^{133}$ Where the WTO case is based on yellow light subsidies, it must be demonstrated that another Member's use of such subsidies is causing 'adverse effects', such as: (1) injury to one of its domestic industries; (2) nullification or impairment of its rights under the Subsidies Agreement; or (3) 'serious prejudice' to any industry in its territory. 'Serious prejudice' is deemed to exist if the incidence of the subsidy is more than 5 percent, or in most instances if there is a forgiveness of a debt to the government or funds are provided to cover the operating losses of an industry or enterprise. ${ }^{134}$ Should the complaining Member prevail with respect to any of the three effects, the subsidizing country would have the usual choice of complying with the decision by eliminating the subsidy or accepting under DSB rules corresponding trade sanctions. ${ }^{135}$

The burden of proving serious prejudice is a significant challenge given the complexities of the evidence likely to be required. In WTO litigation generally, the initial burden of proof rests with the claimant. Under SCM Agreement Article 6.6, if the complainant alleges price undercutting and/or changes in market share or other elements of serious prejudice, it must provide the parties with 'all relevant information that can be obtained ...' Thus, it can be expected that when a Member or Members challenge another Member's subsidies every effort will be made to show that the subsidies are 'contingent in law or in fact' on exporting.

\section{Remedies - national level (CVD)}

National CVDs are contemplated under Part V of the SCM Agreement, as implemented by national CVD laws in many of the Member states. Although there are a number of Members who undertake CVD initiations, there are only a handful of major users, with five nations, the United States, EU, Canada, Australia and Turkey accounting for 82 percent of the 335 CVD actions reported to the WTO through the end of 2013.136

The United States has implemented Part V in its domestic law ${ }^{137}$ in a manner generally considered to be consistent with the Agreement, despite certain challenges that have been lodged before the DSB. ${ }^{138}$ The US Department of Commerce and US International Trade Commission and the EU Commission share an approach that is generally similar to CVD actions under the EU Anti-Subsidies Regulation, so that the same basic considerations apply when either administering authority initiates a CVD investigation. ${ }^{139}$

The SCM Agreement Article 19.1 provides that: 


\section{Research handbook on intellectual property and climate change}

Members shall take all necessary steps to ensure that the imposition of a countervailing duty on any product of the territory of any Member imported into the territory of another Member is in accordance with the provisions of Article VI of GATT 1994 and the terms of this Agreement. Countervailing duties may only be imposed pursuant to investigations initiated and conducted in accordance with the provisions of this Agreement and the Agreement on

Further, if, after reasonable efforts have been made to complete consultations, a Member makes a final determination of the existence and amount of the subsidy and that, through the effects of the subsidy, the subsidized imports are causing injury, it may impose a countervailwithdrawn.

The imposition of CVDs is subject to several important limitations in the SCM Agreement and parallel national laws. Except for developing countries as noted below, ${ }^{141}$ countries may impose CVDs only if subsidies on imported goods in the aggregate total 1 percent or more of the value of the goods. In many industries, if R\&D subsidies are the only actionable ones, it may not be cost-effective to ask the national investigating authorities to undertake an investigation, in part because non-export subsidies will be allocated over production that benefits from the subsidy, including production devoted to domestic use as well as to exports. Also, if those subsidies are used for purchases of capital equipment with useful lives of more than one year, that portion of the subsidy would be allocated over the useful life of the equipment (normally based on the depreciation schedule for such equipment incorporated in the subsidizing Member's income tax laws), a practice that would further reduce the incidence of the subsidy in a given period of investigation.

The use of the CVD laws for a broad assault against imported 'green' goods is generally not feasible. There is no provision in either the SCM Agreement or domestic CVD laws for bringing a case against allegedly subsidized products, 'green' or otherwise, in the aggregate. Rather, competing domestic producers would have to file a CVD action against each subsidized product or group of products individually, a costly and time consuming procedure (with legal and consultant fees in the US commonly running in excess of $\$ 1$ million per action for a ten month administrative proceeding).

As required in the SCM Agreement, CVDs can be imposed only if those subsidies cause injury to the domestic industry in the importing Member (or under US law, 'material injury' to US producers). ${ }^{142}$ This implies that there must be a competing industry in the importing country (or 'the establishment of an industry in the United States [must be] materially retarded'143). Demonstration of material injury under the SCM Agreement and under national CVD laws in both the US and the EU (as with the $\mathrm{ADA}$ and national antidumping laws) requires a showing that imports are increasing, either in absolute or relevant terms, that the domestic industry is being harmed, and that the harm results from such imports. ${ }^{144}$ Only subsidized imports are considered in determining injury.

A detailed discussion of the material injury analysis is beyond the scope of this chapter. It is sufficient to emphasize the need to demonstrate all three elements noted above. Typically, a domestic industry that initiates a CVD action is in difficult economic straits; an industry that is doing well generally does not bring such actions. Causation is normally demonstrated by showing that the imports are being sold at 
lower prices than domestic products, resulting in price undercutting (for example, Chinese products are sold at lower prices than competing American or EU like products) or price suppression (for example, American or EU producers are being forced to reduce their prices to meet Chinese competition). ${ }^{145}$ In the EU, the injury must be to a Community industry and to a major proportion of those enterprises producing like products. ${ }^{146}$

In the United States, and to a considerable degree in the EU and elsewhere, the decision to initiate a CVD action (unlike initiating consultations based on allegations under SCM Agreement Articles 5-6) is not subject to government discretion. For example, if a proper petition is filed and it meets technical legal requirements for sufficiency and for standing, the US authorities are required to initiate an investigation and complete that investigation. Failure to do so is subject to court challenge.

Under the SCM Agreement Article 11.4, as with the ADA, an application for relief must be made 'on behalf of the domestic industry'. Such an application has to be supported by: (1) domestic producers accounting for at least 25 percent of the total domestic production; and (2) domestic producers accounting for at least 50 percent of the collective output of producers expressing any view on the application. ${ }^{147}$ This rule effectively precludes initiation of an action supported by labor groups alone, except in the 'special circumstances' through which a Member government self-initiates a CVD investigation. ${ }^{148}$

Developing countries (which for CVD purposes in the US do not include China and Vietnam) are subject to a de minimis subsidy level of 2 percent, instead of the normal 1 percent. If the aggregate subsidy as determined by the investigating authority is less than the de minimis level, no CVDs may be imposed. Also, if a developing nation's exports represent under 4 percent of the total imports of the affected product, or 9 percent or less in the aggregate for a group of least developed countries (LDCs), they will be excluded from the CVD action (instead of cumulated with the others). ${ }^{149}$ Developed country Members were obligated to eliminate export subsidies immediately, while most developing nations had until 1 January 2003 to comply. The WTO extended this deadline until 2007 for some LDCs. Members who are LDCs, as defined by the United Nations, are excused from the obligation to eliminate export subsidies. However, this does not protect them against CVD cases.

One relatively recent change in US policy has permitted the filing of CVD actions against China (and more recently Vietnam), whether or not they are based on R\&D or support for 'green' technology and production. Until 2006, the Commerce Department took the position that CVD actions under US law could not be applied to NMEs, a position that had been upheld by US courts as within Commerce's discretion. ${ }^{150}$ The essential rationale was that it was impossible to determine the extent to which a 'bounty or grant' (subsidy) existed in a centrally planned economy because the government, rather than market forces, determined the costs of various inputs used in the production of goods, and subsidies could not be separated from other government directives and controls. Under such circumstances, an NME country was subject to an unpredictable methodology for determining the existence of dumping, which tended to exaggerate actual dumping margins, but was essentially insulated from CVD actions designed to offset government subsidies. 


\section{Research handbook on intellectual property and climate change}

However, in 2006 Commerce changed its policy and initiated a CVD investigation against coated paper from China. ${ }^{151}$ While that particular case was ultimately terminated for lack of a material injury to US producers, in a 2008 determination CVDs (at rates of up to 615 percent) were applied to imports into the United States of line pipe. ${ }^{152}$ Nearly 50 CVD investigations against Chinese products have been completed, with the vast majority resulting in or continuing countervailing duty orders. ${ }^{153}$ China has successfully challenged various aspects of the US imposition of antidumping duties and CVDs in the WTO, as applied in specific cases, with the Appellate Body sharply limiting certain procedures followed by US authorities, including the automatic treatment of state owned enterprises in China as 'public bodies'. ${ }^{154}$

There are obvious conceptual inconsistencies between the use of NME methodology in an antidumping case (relying on surrogates, because various input costs are not based on market-determined prices), and the assertion that 'private industry now dominates many sectors of the Chinese economy' so that government subsidies can be accurately measured. The Commerce Department relies, to some extent, on surrogates to determine subsidy benchmarks (such as 'commercial' interest rates). However, Commerce's requirement that 'significantly all' factor input prices must be market driven remains ambiguous and may effectively guarantee that no such industries will be found. ${ }^{155}$ Consequently, a strict market-oriented industry test, as applied by Commerce, virtually guarantees that a market orientated industry will not be found in antidumping actions against NMEs. Logically, under such circumstances, CVD law should not apply because of the lack of market determination of input prices that might be considered government subsidies. ${ }^{156}$

Another significant challenge to the Commerce Department's current methodology relates to Chinese allegations that imposing both antidumping duties and CVDs against NMEs is partially double-counting (and assessing overlapping penalties) in contravention of the GATT 1994. The GATT Article VI.5 provides that "[n]o product of the territory of any contracting party imported into the territory of any other contracting party shall be subject to both antidumping and countervailing duties to compensate for the same situation of dumping or export subsidization'. It is difficult, however, to avoid double-counting in NME CVD actions. First, the existence of dumping and subsidization of exported goods is more difficult to distinguish. ${ }^{157}$ Second, the normal value (the home market side) is determined using a non-subsidized, market-based, surrogatecountry producer, but the actual export prices from the NME enterprises may embody subsidies. Third, the amount of benefit for subsidy purposes is not based on actual prices and commercial loan rates in the NME home market, but on non-national benchmarks (subsidies), often taken from a 'basket' of surrogate countries. The US Court of International Trade (CIT) in a 2010 decision ordered the Commerce Department to cease applying the CVD laws to NMEs until it comes up with a methodology to eliminate double counting. ${ }^{158}$ The Appellate Body reached essentially the same conclusion in March 2011. ${ }^{159}$

\section{Safeguards}

Safeguard measures under GATT Article XIX refer to the practice of imposing temporarily higher import duties or quantitative restraints (quotas), or both, when 
imports are causing serious injury to domestic producers. Safeguards are another anomaly in the GATT, inconsistent with the GATT's principles of trade liberalization. The use of safeguards conflicts with several of the GATT's Articles: Article I MFN non-discrimination treatment for import duties, Article II 'bindings' of tariff levels and Article XI quotas. Like national antidumping laws and the WTO ADA, safeguards have no special application to alternative energy goods or to goods with embedded intellectual property.

The concept of safeguards under WTO law is based on the 'escape clause' of the United States-Mexico Reciprocal Trade Agreement of 1942. ${ }^{160}$ The clause allowed the United States or Mexico to escape its import concessions under the Agreement, where such concessions resulted in increased imports that caused serious injury or threat thereof to a domestic industry. GATT Article XIX was the product of a United States' proposal to incorporate in the international trading system an escape clause very similar to that of the US-Mexico Agreement, providing for the use of safeguards in the event of 'unforeseen developments' resulting from trade concessions. ${ }^{161}$ According to WTO data, Members initiated 279 safeguard investigations between 1 January 1995 and 30 April 2014. The leading notifying Members over the 19-year period were India, Indonesia, Turkey, Jordan, the Ukraine, Poland and the United States. ${ }^{162}$

The Safeguards Agreement provides that:

[a] Member may apply a safeguard measure to a product only if that Member has determined ... that such product is being imported into its territory in such increased quantities, absolute or relative to domestic production, and under such conditions as to cause or threaten to cause serious injury to the domestic industry that produces like or directly competitive products. ${ }^{163}$

Further, '[s]afeguard measures shall be applied to a product being imported irrespective of its source'. ${ }^{164}$

In general, the requirements for investigations reflect the same due process considerations as those for antidumping or CVD material injury investigations. 'Serious injury' is defined as 'a significant overall impairment of the position of a domestic industry'. ${ }^{165}$ Limitations exist on the use of safeguard measures because of the GATT Article XIX requirement of 'unforeseen developments', even when the injury and causation requirements are met. ${ }^{166}$ Because of the absence of any 'unfair' trade practice requirement, moreover, the imposition of safeguards at least theoretically imposes costs on the Member imposing the safeguards (in addition to consumer welfare losses).

Where safeguard measures are applied, compensation through 'a substantially equivalent level of concessions' is required. ${ }^{167}$ In the absence of an agreement, the exporting Member may suspend 'substantially equivalent concessions' after notice to the WTO's General Council. ${ }^{168}$ However, the right of suspension 'shall not be exercised for the first three years that a safeguard measure is in effect, provided that the safeguard measure has been taken as a result of an absolute increase in imports and that such a measure conforms to the provisions of this Agreement'. ${ }^{169}$

Despite the Appellate Body decisions in Argentina - Footwear Safeguards ${ }^{170}$ and US - Steel Safeguards, ${ }^{171}$ which suggest that most safeguard measures are legally inconsistent with the GATT, Article XIX, and the Safeguards Agreement, some Members continue to bring actions to challenge safeguard measures. However, not all safeguards 


\section{Research handbook on intellectual property and climate change}

measures are challenged at the WTO by the exporting Member. Even if such : challenge is lodged, completing the litigation requires $20-24$ months or more, giving the safeguards-imposing Member a free ride during this period because WTO decisions are not retroactive.

A special type of safeguard was applicable only to China, as a result of negotiations over its entry into the WTO, and then only until November 2013. The provision was applicable '[i]n cases where products of Chinese origin are being imported into the territory of any Member in such increased quantities or under such conditions as tc cause or threaten to cause market distuption to the domestic producers of like or directly competitive products ...'. ${ }^{172}$ This authorization is reflected in US law ${ }^{173}$ but was used by the United States only once - by the Obama Administration with regard to passenger vehicle tires. ${ }^{174}$ During the second Bush Administration, the US International Trade Commission considered several Section 421 petitions between 2002 and 2005 , recommending safeguard relief; President Bush declined to provide remedies in all such instances. ${ }^{175}$ China unsuccessfully challenged the US Section 421 tires action at the WTO, ${ }^{176}$ with predictable results given China's acceptance of the mechanism in its Accession Protocol. ${ }^{177}$

\section{Section 337 of the 1930 Tariff Act (United States)}

Section 337 provides a unique remedy to US industries for 'unfair competition' that injures an industry or threatens the establishment of an industry in the United States. The statute covers not only intellectual property violations - copyright, patent, trademark, and computer chip mask infringement - but also other types of unfair competition such as false advertising, false designation of origin, theft of trade secrets, and passing off copies as genuine articles. Of over 400 Section 337 investigations initiated since 1975, well over half have involved intellectual property. Thus, US intellectual property holders have in their arsenal a powerful remedy in the event that imports infringe US patents.

Section 337 is particularly well suited to the protection of patents, trademarks, copyrights, semiconductor chip masks and industrial designs because no injury test is required, in contrast to other Section 337 'unfair competition' actions. Rather, an intellectual property holder must only demonstrate that 'an industry in the United States, relating to the articles protected by the patent, copyright, trademark, mask work, or design concerned, exists or is in the process of being established'. ${ }^{178}$ Under the statute, an industry in the United States shall be considered to exist if there is in the United States, with respect to the protected articles: (A) significant investment in plant and equipment; (B) significant employment of labor or capital; or (C) substantial investment in its exploitation, including engineering, research and development, or
licensing. ${ }^{179}$

In 1989, a GATT Panel held the original version of Section 337 to be inconsistent with the United States' GATT obligations. ${ }^{180}$ TRIPs requires that national enforcement procedures be 'fair and equitable ... [and] not be unnecessarily complicated or costly, or entail unreasonable time limits'. ${ }^{181}$ The current version of Section 337 is designed to comply with these requirements. As of 1995, Section 337 permits counterclaims, precludes simultaneous infringement actions before both the US International Trade 
Commission (USITC) and the federal courts, precludes in rem enforcement, and in general no longer permits unduly onerous procedural requirements for foreign respondents. To date, the revised Section 337 has not been challenged in the WTO.

US law maintains an essentially discriminatory element in Section 337, in the sense that it is a remedy available to US producers against foreign producers only, not against infringing US manufacturers. For example, Texas Instruments may bring a Section 337 action against semiconductors made by Samsung Electronics in Korea and exported to the United States, but not against similar devices made and sold by IBM or Intel in the United States. This discriminatory aspect is legal under TRIPs, which recognizes that effective international enforcement of intellectual property rights may require remedies different from those available against domestic producers, as obtaining jurisdiction over the foreign entities in US courts may be impossible. ${ }^{182}$

In addition to the absence of any proof of injury requirements, a Section 337 action is attractive to US petitioners in large part because of its draconian remedy: if a foreign product is found, for example, to infringe a valid US patent, products utilizing the patented technology can be entirely excluded from entry into the United States. ${ }^{183}$ However, unlike in US federal court actions, no monetary remedies may be obtained against the infringing producer. The exclusionary remedy provides powerful negotiating leverage for the US petitioner. It is thus no surprise that most Section 337 actions are settled either through the issuance of a 'cease and desist' order by the US International Trade Commission or through a settlement that contemplates the conclusion of a royalty-payment licensing agreement between the US patent holder and the allegedly infringing foreign producer. Because the action is enterprise-specific, meaning that the violation is usually of a patent or right owned by a single enterprise or individual rather than an entire industry, the action need not receive broader industry support (as is required for antidumping or CVD actions as noted above).

Procedurally, a Section 337 action resembles a US district court action. However, the cases tend to be resolved more quickly and the rules of evidence are less stringent. Determinations are initially made before an administrative law judge at the USITC. However, unlike antidumping and CVD injury 'investigations', Section 337 actions are formal 'adjudications' subject to the US Administrative Procedure Act. ${ }^{184}$

Typically, a Section 337 petition alleges that an imported product (for example, solar panels) infringes a US patent or other intellectual property rights registered or otherwise obtained in the United States. As in the federal courts, counterclaims challenging the validity of the patent (or other intellectual property right) may be lodged as part of the proceeding. Section 337 also applies to various types of 'unfair competition' related situations, such as eco-labeling, making false claims of efficiency, or employing a 'trade dress' (appearance of the foreign product) that is confusingly similar to the competing domestic product.

\section{US Section 301 and Special 301}

From the 1960s until at least 1995, when the WTO and TRIPS Agreement entered into force, the US government experienced frustration as many of the international trade problems faced by US firms - particularly those relating to service market access and 


\section{Research handbook on intellectual property and climate change}

to protection by other nations of US intellectual property rights -were not covered by the GATT. Sections 301-306 were enacted in the 1974 Trade Act to deal with these concerns. ${ }^{185}$

Section 301 is the most controversial of the US trade remedy laws. ${ }^{186}$ It has been attacked periodically by US trading partners as rampant unilateralism, a statute which allegedly shows US arrogance in terms of ignoring the international rules. In scope and potential coverage, it is one of the broadest US trade remedy laws, affording the US Trade Representative (USTR) considerable discretion in initiating and pursuing cases. Although US Section 301 actions have addressed a wide variety of alleged violations (including services), a substantial number have focused on foreign government failures to enforce intellectual property laws. Unlike the other trade remedies discussed in this section, Section 301 addresses alleged unfair practices in or by foreign countries, either instead of or in addition to those relating to imports into the United States. The possible applications to 'green' technology products include challenges to compulsory licensing of US technology by foreign governments under the TRIPS Agreement and failures by Members to comply with their enforcement obligations under that Agreement. Such actions could also be pursued in the DSB, but given a moratorium on the so-called 'non-violation' complaints, they would have to demonstrate violations of the TRIPS Agreement in order to be effective. More broadly, Section 301 can also be used to challenge government subsidies, particularly where the effects are broader than just the US import market, and any other alleged violation of one or more of the WTO Agreements.

This was the case with the Section 301 petition discussed earlier, which was filed by the United Steelworkers in September 2010 and resulted in a settlement in March 2011 in which China agreed to eliminate various illegal import substitution subsidies. To date, the USTR has avoided a 'broadside' attack against the subsidization of renewable energy by other WTO Members. But the use of Section 301 to deal with such problems in the future remains likely.

Section 301 is most logically viewed as having a dual purpose. First, under US domestic law, it provides a procedure for a domestic industry to petition USTR to initiate an action remedying a foreign government's violations of trade agreements, or 'unreasonable' or 'discriminatory' actions abroad that burden or restrict US commerce. This private form of action is desirable, as only governments can bring legal actions in the WTO challenging other governments' policies. Second, Section 301 provides a framework for bilateral negotiations, resort to multilateral mechanisms (such as the WTO's DSB or NAFTA's Chapter 20), and, ultimately, for retaliation against violators.

Section 301(a) provides for 'mandatory action' by the USTR to take action against other countries. ${ }^{187}$ In other words, when an alleged violation comes within the requirements of Section 301(a), USTR (at least in theory) must move forward with a process that will likely result either in a negotiated settlement or a WTO action.

By contrast, Section 301(b) provides for discretionary action: 'Where USTR determines that a particular act, policy or practice of a foreign country is unreasonable or discriminatory and burdens or restricts U.S. commerce, it has discretion as to whether to take retaliatory action.' For all practical purposes, Section 301(b) is effectively available for use only against non-Members of the WTO because the types of retaliation contemplated by the statute (increased tariffs or quotas, or a combination 
of the two) cannot, since 1 January 1995, be imposed on other WTO Members, except with authorization from the DSB.

The DSB rejected a broad, early challenge to Section 301 by the EU, but only after the United States promised to use the mechanism only in conjunction with the WTO's dispute settlement process. ${ }^{188}$ Under these circumstances, Section 301 is best characterized as administrative mechanism for raising potential violations formally with the USTR and for demanding that USTR initiate negotiations and, ultimately, initiate and pursue a WTO DSB action. However, it should be noted that the USTR often initiates consultations in the DSB without domestic stakeholders having filed formal Section 301 petitions, when USTR considers it in the United States' economic interest to do so.

Intellectual property protection has been a frequent subject of Section 301 actions against China (at least four times), Korea, India, Brazil, and Taiwan, among others. ${ }^{189}$ The United States viewed as 'unreasonable' under Section 301 these foreign governments' alleged denials of what the US considered to be adequate protection against, inter alia, piracy, counterfeiting and the integrity of patent rights, even though before 1995 there were no WTO obligations in this area.

Special 301 is a separate statute that also dates from $1974 .{ }^{190}$ It creates a mechanism requiring the USTR to review annually other nations' compliance with international intellectual property rules. Under Special 301, the USTR annually publishes a 'Special 301 Report', which characterizes the deficiencies in intellectual property protection among more than 50 of the United States' trading partners, and places them into a 'watch list' and 'priority watch list'. Placement on the priority list triggers investigations and negotiations, with the possibility of being followed by actions brought in the DSB. The 2014 priority watch list included not only China, Russia and India, but also Algeria, Argentina, Chile, India, Pakistan, Thailand and Indonesia. ${ }^{191}$ China was cited, inter alia, for obstacles to effective protection of IPR in all forms, counterfeiting of various products, compulsory transfer of patents from foreign to domestic entities as a condition of market access and innovation-related policies that are discriminatory against foreigners. ${ }^{192}$

\section{CONCLUSION}

The international trade rules set out in the GATT and other WTO Agreements will have a significant impact on the complex and unpredictable worldwide efforts to address global climate change. Whether these rules ultimately facilitate trade in alternative energy products and services or impede such commerce will depend on a range of presently unknown factors. These include whether new WTO Agreements are concluded to reduce or eliminate tariffs and other restrictions on trade in environmental goods and services, and to renew the non-actionable treatment of 'Green Light' (R\&D and environmental cleanup) subsidies. If the world's major GHG producing nations ultimately reach agreement on a schedule for reduction of greenhouse gases, the risk of unilateral import restraints to level the playing field between nations that regulate GHG emissions and those who do not will be minimized. Otherwise, the use of border carbon taxes and similar measures (many of which may be WTO legal, as discussed above) is likely to proliferate. 


\section{Research handbook on intellectual property and climate change}

Other questions will arise over whether the key technologies needed to effective deal with GHG reductions and energy security will be freely transferred, or instead w become the subject of restrictive trade actions (and intellectual property disputes) in t United States and elsewhere. Even with some accommodations among trading natio there remains a significant risk that developed country manufacturers and their unio may seek to stem the flow of production of alternative energy and other green produc to lower wage-cost countries. They may seek to employ antidumping, subsidy, a other trade actions, or to impose questionable technical standards, as was the case wi the outflow of manufacturing jobs beginning 30-35 years ago. Finally, one $\mathrm{m}$ reasonably question the extent to which the need to reduce GHG emissions world-wi can overcome more parochial interests like fears of retarded economic development al job creation, even among those nations in which the scientific existence of a hum impact on climate change is not being questioned.

\section{NOTES}

1. See Klepper, G. and S. Peterson (2003), 'International trade and competitiveness effects', Emissio Trading Policy Briefs 6 CATEP Project, Environmental Institute, 3; Reinaud, J. (2008), 'Issues behi competitiveness and carbon leakages, focus on heavy industry', IEA Information Paper, OECD/IE 17.

2. See United Nations (2015), 'Towards a Climate Agreement', available 20 November 2015 http://www.un.org/climatechange/towards-a-climate-agreement/.

3. See http://www.un.org/climatechange/blog/2015/02/governments-track-reaching-paris-2015-univers: climate-agreement, available 20 November 2015. For the official negotiation text, see http unfccc.int/documentation/documents/advanced_search/items/691 I.php?priref $=600008407$, available : November 2015.

4. See M. Nachmany et al. (2014), The Globe Climate Legislation Study: A Review of Clima Legislation in 66 Countries (Globe Int'l \& Grantham Research Inst., London Sch. Econ. 4th ed available 20 November 2015 at http://www.globeinternational.org/pdfviewer.

5. Bachus, J. (16 June 2010), 'Questions in search of answers: trade, climate change and the rule of las (keynote address), Thinking Ahead on International Trade programme for the Centre for Trade ar Economic Integration at the Graduate Institute, Geneva, Switzerland, 2, available 20 November 201 at http://graduateinstitute.ch/files/live/sites/iheid/files/sites/ctei/shared/CTEI/events/TAIT\%202/Keynot $\epsilon$ Bacchus_Final_Plus_Discussions.pdf.

6. Abaza, Hussein, et al. (2009), Trade and Climate Change: WTO-UNEP Report, Geneva, Switzerlanı WTO Publications, 151 [WTO-UNEP Report, available 20 November 2015 at http://www.wto.or english/res_e/publications_e/trade_climate_change_e.htm].

7. Ibid, at 87-9.

8. See generally Low, P., G. Marceau, and J. Reinaud (2011), 'The interface between the trade an climate change regimes: scoping the issue', available 20 November 2015 at http://www.wto.or: english/res_e/reser_e/ersd201101_e.pdf; Low, P., G. Marceau, and J. Reinaud (2010), 'The interfac between the trade and climate change regimes: scoping the issue', Staff Working Paper ERSD-2011Thinking Ahead on International Trade Programme for the Centre for Trade and Economic Integratio at the Graduate Institute, Geneva, Switzerland, 5, available 20 November 2015 at https://www.wto.or english/res_e/reser_e/ersd201101_e.pdf; Cosbey, A. (ed.) (2008), Trade and Clinate Change: Issutes i Perspective, Winnipeg, Canada: International Institute for Sustainable Development; Sugathar Mahesh et al., 'Liberalization of trade in environmental goods for climate change mitigation: th sustainable development context', Background Paper for the Trade and Climate Change Semina Winnipeg, CA: International Institute for Sustainable Development; Cottier, Thomas, Olga Nartove and Sadeq Z. Bigdeli (eds) (2009), International Trade Regulation and the Mitigation of Climat Change: World Trade Forum, Cambridge and New York: Cambridge University Press; Senat Committee on Finance, 'Climate change trade measures: estimating industry effects', Statement o 
Loren Yager, Director International Affairs and Trade, 111th Cong., 2009; Huffbauer, G.C., S. Charnovitz and S. Kim (2009), Global Warming and the World Trading System, Washington, DC: Petersen Institute; Gallagher, K.P. (2008), Handbook on Trade and the Eıvironment, Cheltenham, UK and Northampton, MA, USA: Edward Elgar Publishing; World Bank (2008), International Trade and Climate Change, Washington, DC: World Bank; Bhala, R. (2005), Modem GATT Law, London: Sweet \& Maxwell; Matsushita, M., T.J. Schoenbaum and P.C. Mavroidis (2006), The World Trade Organization: Law, Practice, and Policy, Oxford: Oxford University Press; Committee on Technical Barriers to Trade, 'Decisions and recommendations adopted by the Committee since 1 January 1995 : Note by the Secretariat', G/TBT/1/Rev.8 (23 May 2002); Committee on Trade and Environment, 'List of working documents', WT/CTE/INF/3 (29 January 2001); Stewart, T.P. (1996), 'The World Trade Organization', Chicago, IL: ABA; Jackson, John (1989), The World Trading System: Law and Policy of International Economic Relations, Cambridge, MA: MIT Press.

9. EU documents, decision and analysis are available, inter alia, at the official website of the EU, http://europa.eu/. A comprehensive source for NAFTA texts and dispute settlement rulings is the website of the US section of the NAFTA Secretariat, available 15 December 2015 at https:/ www.nafta-sec-alena.org/Home/Welcome. The North American Agreement on Environmental Cooperation (NAAEC) can be found on the website of the Commission on Environmental Cooperation (CEC), available 15 December 2015 at http://www.cec.org/Page.asp?PagelD= $1226 \&$ SiteNodeID $=567$.

10. General Agreement on Tariffs and Trade 1994, 15 April 1994, Marrakesh Agreement Establishing the World Trade Organization, Annex 1A [GATT 1994].

11. General Agreement on Trade in Services, 15 April 1994, Marrakesh Agreement Establishing the World Trade Organization, Annex 1B [GATS].

12. Sumner, J., L. Bird, and H. Smith (2009), 'Carbon taxes: a review of experience and policy design considerations', Oak Ridge, TN: U.S. Department of Energy, available 20 November 2015 at www.nrel.gov/docs/fy10osti/47312.pdf.

13. Stavins, R.N. (2001), 'Experience with market-based environmental policy instruments', Discussion Paper 01-58, Washington, DC: Resources for the Future.

14. WTO-UNEP Report, at 92. The National Emission Trading System includes the European Union, Switzerland, New Zealand, Australia, South Korea, and Kazakhstan. The International Emission Trading program, the Kyoto Protocol program under the clean Development Mechanism (CDM) provides for trading across nations. See http://unfecc.int/resource/docs/convkp/kpeng.pdf, available 20 November 2015.

15. Ibid, at 99 .

16. See, e.g., American Clean Energy and Security Act H.R. 2454 [Waxman-Markey Bill]; Turin, Dustin R. (2012), 'The Challenged of Climate Change Policy: Explaining the Failure of Cap and Trade in the United States With a Multiple-Stream Framework', Student Pulse, 4 (6), 1-3.

17. See Intergovernmental Panel on Climate Change, Summary for Policymakers, in Climate Change 2014: Mitigation of Climate Change -Contribution of Working Group III to the Fifth Assessment Report of the Intergovernmental Panel on Climate Change.

18. Agreement on Technical Barriers to Trade, 15 April 1994, Marrakesh Agreement Establishing the World Trade Organization, Annex 1A [TBT Agreement]; Agreement on Subsidies and Countervailing Measures, 15 April 1994, Marrakesh Agreement Establishing the World Trade Organization, Annex 1A [SCM Agreement].

19. See, e.g. The Economist (2010), 'Green view: how to save $\$ 300$ billion', available 20 November 2015 at http://www.economist.com/blogs/newsbook/2010/11/fossil-fuel_subsidies; Biello, D. (2009), 'How much in subsidies do fossil fuels get anyway?', available 20 November 2015 at http://www. scientificamerican.com/blog/post.cfm?id=how-much-in-subsidies-do-fossil-fue-2009-09-18.

20. WTO-UNEP Report at 114

21. Ibid, at 115 .

22. See WTO (2015), Activities of the WTO and the challenge of climate change, available 20 November 2015 at http://www.wto.org/english/tratop_e/envir_e/climate_challenge_e.htm.

23. See generally Christiane R. Conrad (2011), Processes and Production Methods (PPMs) in WTO Law: Interfacing Trade and Social Goals, Cambridge: Cambridge University Press.

24. Appellate Body Report, European Communities - Measures Prohibiting the Importation and Marketing of Seal Products, II 5.12, WT/DS400/AB/R, WT/DS401/AB/R (22 May 2014) [hereinafter: Appellate Body Report, EC-Seal Products]. See ibid, TWt 5.28-5.29 (reversing the panel's finding that the EU Seal Regime constitutes a technical regulation under TBT Annex $1: 1$ and finding that the panel 


\section{Research handbook on intellectual property and climate change}

improperly characterized the measure - the prohibition on seal-containing products - as laying down product characteristics without analyzing the weight and relevance of each of the essential and integral elements of the measure as an integrate whole and fully examining the design and operation of the measure). But see ibid, श⿴囗 5.69-5.70 (noting that the line between PPMs that fall, and those that do not fall, within the scope of the TBT Agreement raises important systemic issues, and declining to completing the legal analysis by ruling on whether the EU Seal Regime lays down 'related PPMs' within the meaning of Annex 1.1 to the TBT Agreement).

25. Ibid, at 119

26. Ibid, at 120

27. GATT 1994, Article I (emphasis added).

28. Marceau, Gabrielle, 'The New TBT Jurisprudence in US - Clove Cigarettes, WTO US - Tinna II, and US - COOL', 8 Asian J. WTO \& Int'l Health L \& Pol'y 1, 8 n. 20 (2013).

29. See Panel Report, United States - Restrictions on Imports of Tuma, 中t 5.14-5.15, 5.18, DS21/R, 3 (3 September 1991), GATT B.I.S.D. 39S/155 (unadopted) [US - Tuma I Panel Report]; Panel Report, United States - Measures Concerning the Importation, Marketing and Sale of Tuma and Tuna Products, WT/DS381/R (15 September 2011) [US - Tuna II Panel Report].

30. Appellate Body Report, US - Tima II, I 406.

31. GATT Panel Report, 'Belgian family allowances (allocations families)', II 2, G/32 - 1S/59, 6 November 1952.

32. Appellate Body Report, Indonesia - Certain Measures Affecting the Automobile Industry, II 15.1(c), WT/DS54/15, WT/DS55/14, WT/DS59/13, WT/DS64/12, 23 July 1998 [indonesia - Automobiles].

33. Charnovitz, S. (2002), "The Law of Environmental "PPMs" in the WTO: Debunking the Myth of Illegality', Yale J. Int'l L. 27 (59), 83-5.

34. Report of the Working Party, 'Border Tax Adjustments', II 5, L/3464, 2 December 1970, [Border Tax Adjustments].

35. See Kulovesi, Kati (2014), 'Real or Imagined Controversies? A Climate Law Perspective on the Growing Links between the International Trade and Climate Change Regimes', Trade L. \& Dev. 55.

36. GATT 1994, Article II.2(a).

37. WTO-UNEP Report, at 100

38. Ibid, at 100 .

39. 'Border tax adjustments', II 7, L/3464.

40. WTO-UNEP Report, at 103.

41. See United States - Tax Treatment for 'Foreign Sales Corporations', WT/DS108/AB/35 (2006).

42. 'Border Tax Adjustments', II 32, L/3464.

43. Report of the Panel, 'United States tax legislation (DISC)', II 58, L/4422, 12 November 1973, GATT B.I.S.D (23rd Supp.) at 98 (1981).

44. Pauwelyn, J. (2007), 'U.S. federal climate policy and competitiveness concerns: the limits and options of international trade law', Working Paper, Nicholas Institute for Environmental Policy Solutions, Duke University, Durham, North Carolina, 17-18; see 'Border Tax Adjustments', II 15, L/3464.

45. Low, at 8-9.

46. GATT 1994, Article III (emphasis added).

47. Appellate Body Report, Japan - Taxes on Alcoholic Beverages, 抱 18-19, WT/DS8/AB/R, 4 October 1996.

48. Ibid, TIII 27-29.

49. Appellate Body Report, Korea - Measures Affecting Imports of Fresh, Chilled and Frozen Beef, III 135-138, WT/DS161/AB/R, 11 December 2000, [Korea - Beef AB Report].

50. Appellate Body Report, Dominican Republic - Measures Affecting the Importation and Internal Sale of Cigarettes, T1 96, WT/DS302/AB/R, 25 April 2005, [Dominican Republic - Cigarettes AB Report]

51. Appellate Body Report, European Communities - Measures Affecting Asbestos and Products Containing Asbestos, II 101, WT/DS 135/AB/R, (12 March 2011) [EC - Asbestos AB Report].

52. See, e.g., Tuna - Dolphin Panel Report, T1 5.14.

53. EC - Asbestos AB Report, TI 109.

54. See, e.g., EC-Asbestos AB Report, 11114

55. See US - Tima I Panel Report, II 195.

56. Report of the Panel, United States - Restrictions on Imports of Tima, TI 5.10, 5.35, DS21/R, 3 September 1991, GATT B.I.S.D (39th Supp.) at 155 (unadopted) [Tima - Dolphin Panel Report] 
57. Panel Report, Indonesia - Certain Measures Affecting the Automobile Industry, IIII 14.33-14.36, 14.39, 14.56, WT/DS54/R, WT/DS55/R, WT/DS59/R, WT/DS64/R (July 23, 1998) [Indonesia-Automobiles Panel Report].

58. See, e.g., GATT 1994, Article X; Ala'i, Padideh (2008), 'From the Periphery to the Center? The Evolving WTO Jurisprudence on Transparency and Good Governance', J. Int'l Econ. L. 1, 779.

59. Report of the Panel, United States - Antidumping Measures on Certain Hot-Rolled Steel from Japan, q 7.268, WT/DS174/R, 28 February 2001.

60. Ala'i, at 779 .

61. Low, at 12.

62. EC - Asbestos AB Report, II 172.

63. Korea - Beef AB Report, \TI162-63.

64. Appellate Body Report, Brazil - Measures Affecting Imports of Retreaded Tyres, TII 156, 211, WT/DS332/AB/R, 3 December. 2007 [Brazil - Tyres AB Report].

65. Brazil - Tyres AB Report, at 156.

66. Tima - Dolphin Panel Report, at XX.

67. Appellate Body Report, United States - Standards for Reformulated and Conventional Gasoline, II 20, WT/DS2/AB/R, 29 April 1996, [US - Gasoline AB Report].

68. US - Shrimp AB Report, 1136.

69. See, e.g., US - Gasoline AB Report, q4 23-24.

70. See, e.g., US - Shrimp AB Report, 96 158-59.

71. Appellate Body Report, European Commumities - Measures Concerning Meat and Meat Products (Hormones), If 208, WT/DS26/AB/R, WT/DS48/AB/R, 16 January 1998.

72. See Appellate Body Report, United States - Import Prohibition of Certain Shrimp and Shrimp Pert. 21. I 152, WT/DS58/AB/R, 21 November 2001; Howse, R. (2002), "The Appellate Body Rulings in the Shrimp/Turtle Case: A New Legal Baseline for the Trade and Environment Debate', Coltum. J. Envtl. L. 27, 491.

73. See United Nations Framework Convention on Climate Change, 21 March 1994, Arts. 3-4, 1771 UNTS 107, 109 (UNFCCC); Kyoto Protocol, Art. 3 U.N. Doc FCCC/CP/1997/7/Add. 1, 10 December 1997, 37 ILM 22, 33-4.

74. Appellate Body Report, European Conmunities - Trade Description of Sardines, $\mathbb{1}$ 176, WT/DS231/ AB/R (26 September 2002) [EC - Sardines AB Report]; EC - Asbestos AB Report, qUS 66-70.

75. US - Gasoline AB Report, 9II 30-31; Korea - Beef AB Report, शाt 161-62

76. See Panel Report, United States - Measures Affecting the Production and Sale of Clove Cigarettes, If 7.369 [US - Clove Cigarettes].

77. See TBT Agreement, Art. 2.4 .

78. See ibid, Art. 2.5 .

79. EC-Sardines AB Report, पI 227.

80. Low, at 26.

81. WTO-UNEP Report, at 125 .

82. WTO Agreement on Government Procurement, Annex 4, 15 April 1994, Marrakesh Agreement Establishing the World Trade Organization, Annex 1A

83. See WTO (2011), Parties and Observers to the GPA, available 20 November 2015 at http:// www.wto.org/english/tratop_e/gproc_e/memobs_e.htm\#parties.

84. See https://www.wto.org/english/tratop_e/gproc_e/gp_gpa_e.htm (available 20 November 2015).

85. WTO Agreement on Trade-Related Investment Measures, Annex, q1 1(a), 15 April 1994, Marrakesh Agreement Establishing the World Trade Organization, Annex 1A, 1868 U.N.T.S. 186 [TRIMS Agreement].

86. Indonesia - Automobiles, II 15.1. REV1: The Multilateral Agreement on Investment: Commentary to the Consolidated Text, DAFFE/ REV1; The Multilateral Agreement on lnvestment: Commentary to datso the datase containing documents from the negotiations, available 20 November 2015 at http://wwwl loecd.org/daf/mai/index.htm.

88. Petition for Relief Under Section 301 of the Trade Act of 1974, as amended: China's Policies Pffecting Trade and Investment in Green Technology on behalf of the United Steel, Paper and Forestry, Rubber Workers International Union, 9I 91-110, 9 September 2010 [United Steelworkers Section 301 Petition]. 


\section{Research handbook on intellectual property and climate change}

89. 'U.S. requests consultations with China over wind power subsidies', Inside U.S. Trade, 24 December 2010; Pruzin, D. (2011), 'China said to eliminate wind power subsidy at center of WTO Proceeding with U.S.', Int'l Env. Rptr: (BNA) 34, 582.

90. General Agreement on Trade in Services, 15 April 1994, Marrakesh Agreement Establishing the World Trade Organization, Annex IB [GATS].

91. Jackson, J.H., W.J. Davey and A.O. Sykes, Jr. (2008), Legal Problems of International Economic Relations: Cases, Materials and Text (4th edn), Minneapolis: West Publ., 885 [Jackson, Davey, and Sykes].

92. Jackson, Davey, and Sykes, at 885

93. GATS, Article XIV(b).

94. GATT Secretariat, 'Services sectorial classification list', GATT/WTO Doc MTN.GNS/W/120 (1991) [W/120 List].

95. Nartova, O. (2009), Assessment of GATS' Impact on Climate Change Mitigation, in Cottier, Thomas et al. (eds), Intemational Trade Regulation and the Mitigation of Climate Change, Cambridge: Cambridge University Press, 259 [Nartova].

96. Delimatsis, P. and D. Mavromat (2009), GATS, Financial Services and Trade in Renewable Energy Certificates (RECS) - Just Another Market Based Solution to Cope with the Tragedy of the Commons?, in Cottier, Thomas et al. (eds), Intemational Trade Regulation and the Mitigation of Climate Change, Cambridge: Cambridge University Press, 231 [Delimatsis and Mavromat].

97. GATS, Second Protocol: Financial Services. This Protocol under GATS was adopted 2 July 1995 and entered into force on 1 September 1996.

98. Delimatsis and Mavromat, at 231

99. GATS, Second Protocol: Financial Services, Annex, II 5(a).

100. See Nartova.

101. See W/120 List.

102. Doha WTO Ministerial 2001: Ministerial Declaration, Nov. 14, 2001, para. 31(iii), available 20 November 2015 at https://www.wto.org/english/thewto_e/minist_e/minol_e/mindecl_e.htm.

103. Bracken, L.L. (2015), 'Sixth Round of Environmental Goods Talks Set for Early May, Moving into Second Phase,' Imt'l Trade Rpt; (BNA), 32, 672.

104. See APEC (18 May 2015), 'APEC Moves to Cut Environmental Goods Tariffs as Deadline Looms', available 20 November 2015 at http://www.apec.org/Press/News-Releases/2015/0518_EG.aspx.

105. See David A. Gantz (2015), Liberalizing Intemational Trade After Doha: Multilateral, Plurilateral, Regional and Unilateral Initiatives, Cambridge: Cambridge University Press, pp. 81-4.

106. For a detailed discussion of US antidumping, countervailing duty and safeguards laws, see Gregory W. Bowman, et al. (2010), Trade Remedies in North America, New York: Wolters Kluwer, chs. 3, 7.

107. Breakthrough Institute Data (6 August 2010), 'Going Green: Picking Winners, Saving Losers', The Economist, available 20 November 2015 at http://www.economist.com/node/16741043?story_id=
16741043.

108. See T. Cottier and D. Baracol (2009), WTO Negotiations on Emirommental Goods and Services: A Potential Contribution to the Millennium Development Goals, UNCTAD, UNCTADUNCAD/DITC/
TED/2008/4.

109. See 19 U.S.C. $\$ \$ 1601,1671$; 19 U.S.C. $\$ \$ 1337$ et seq.

110. WTO, Antidumping Initiations by Reporting Member 1 January 1995-31 December 2013, available 20 November 2015 at http://www.wto.org/english/tratop_e/adp_e/adp_e.htm.

111. GATT 1994, Article VI(1).

112. 'Agreement on Implementation of Article VI of the General Agreement on Tariffs and Trade 1994', 15 April 1994, Marrakech Agreement, Annex IA [hereinafter Antidumping Agreement or ADA].

113. Appellate Body Report, United States - Definitive Anti-Dumping and Countervailing Duties on Certain Products from China, WT/DS379/AB/R, 25 March 2011, ๆlT 605-6.

114. WTO, 'Antidumping initiations by reporting member and antidumping measures by importing Member', 1 January 1995 to 30 June 2010, available 20 November 2015 at http://www.wto.org/ english/tratop_e/adp_e/adp_e.htm.

115. See art. 5.4 of the Antidumping Agreement, art. 11.4 of the Agreement on Subsidies and Countervailing Measures.

116. Antidumping Agreement, Art. 5.4; SCM Agreement, Art. 11.4

117. United Steelworkers Section 301 Petition.

118. Arch Chems., Inc. v. United States, 2009 Ct. Intl. Trade LEXIS 78 (Ct. Int'1 Trade 13 July 2009).

119. 19 U.S.C. § $1677(18)(\mathrm{A}-\mathrm{B})$. 
120. See (10 November 2001), 'China: accession of the People's Republic of China', q 15, available 20 November 2015 at http://www.wto.org/english/thewto_e/acc_e/completeacc_e.htm\#list; 'Vietnam, protocol of accession', 15 November 2006; Working Party Report, 27 October 2006, III 254-5, available 20 November 2015 at http://www.wto.org/english/thewto_e/acc_e/completeacc_e.htm\#vnm.

121. See, e.g., Lantz, R. (1995), 'The Search for Consistency: Treatment of NMEs in Transition under the US AD and CVD Law', Am. U. J. Int'l L. \& Pol'y 10, 993.

122. SCM Agreement, Arts. 1.1(a)(1)(i), (a)(2).

123. SCM Agreement, Art. 1.1.

124. SCM Agreement, Arts. 1.2, 2.1.

125. SCM Agreement, Arts. 1, 3 and 8, respectively.

126. SCM Agreement, Art. 31.

127. 19 U.S.C. $\S 1677(5 B)(G)$.

128. WTO, 'Declaration on Implementation-Related Issues and Concerns', 14 November 2001, II 10.2 (emphasis supplied), available 20 November 2015 at http:/www.wto.org/english/thewto_e/minist_e/ min01_e/mindecl_implementation_e.htm.

129. SCM Agreement, Art. 5.

130. Appellate Body Report, European Communities and Certain Member States - Measures Affecting Trade in Large Civil Aircraft, WT/DS316/AB/R, 1 June 2011, III $1047-48$.

131. SCM Agreement, Arts. 8 (defining 'Green Light' subsidies), 31 (providing for their expiration five years after 1 January 1995).

132. SCM Agreement, Part 5.

133. SCM Agreement, Arts. 3-4.

134. SCM Agreement, Arts. 5, 6 .

135. WTO, 'Understanding on Rules and Procedures Governing the Settlement of Disputes', 15 April 1994, Annex 2, Marrakech Agreement, Arts. 21-22.

136. WTO, 'Countervailing initiations: by reporting Member I January 1995-31 December 2013', available 20 November 2015 at http://www.wto.org/english/tratop_e/scm_e/scm_e.htm.

137. Tariff Act of 1930 , as amended, 19 U.S.C. $\$ \S 1671$ et seq.

138. See, e.g., United States - Final Dumping Deiermination on Softwood Lumber from Canada, WT/DS264/AB/R, 31 August 2004.

139. See, e.g., 19 U.S.C. § 1677(5), (5A); Council Regulation (EC) No. 2026/97, [1997] OJ L288/, as amended by Council Regulation 461/2004, [2004] OJ L77/2.

140. SCM Agreement, Art. 10; see 19 U.S.C. $\$ 1671 \mathrm{~b}(\mathrm{~b})(4)$.

141. SCM Agreement, Art. 11.9; 19 U.S.C. $\$ 1671 \mathrm{~b}(\mathrm{~b})(4)$

142. 19 U.S.C. $\$ 1671$ (b); EU Anti-Subsidies Regulation, Art. 8(1); SCM Agreement, Art. 15 (reflecting GATT, Art. VI).

143. 19 U.S.C. § $1671(\mathrm{a})$.

144. SCM Agreement, Art. 15.1; see Anti-Subsidies Regulations, Art. 8(1).

145. SCM Agreement, Art. 15.2.

146. EU Anti-subsidies Regulation, Art. 9(1).

147. SCM Agreement, Art. 11.4; 19 U.S.C. $\$ 1671 \mathrm{a}(\mathrm{c})(4)$.

148. SCM Agreement, Art. 11.6.

149. SCM Agreement, Art. 27.10(a).

150. Georgetown Steel Corp. v. United States, 801 F.2d 1308 (Fed. Cir. 1986).

151. Department of Commerce, 'Notice of investigation of countervailing duty investigations: coated free sheet paper from the People's Republic of China, Indonesia and the Republic of Korea', 27 November 2006, 71 Fed. Reg. 68, 546.

152. USITC (26 June 2008), 'Affirmative injury finding in pipe case is first time CVD duties to apply to China', Int'l Trade Rep. (BNA) 25, 960.

153. See USITC (2014), AD/CVD Completed Investigations.

154. Appellate Body Report, United States - Definitive Anti-Dumping and Countervailing Duties on Certain Products from China, WT/DS379/AB/R, 25 March 2011.

155. Tatelman, T.B. (2007), 'United States' trade remedy law and NMEs: a legal overview', CRS Report for Congress, Order Code RL 33976 (citing L.J. Bogard and L.C. Menghetti (1992), 'The Treatment of NMEs under the US AD and CVD Law: A Petitioner's Perspective', PLI Corp. Law and Practice Course Handbook, Series No. 789, 6-7). 


\section{Research handbook on intellectual property and climate change}

156. Laroski, J.A. (1999), 'NMEs: A Love Story: NME and Market Economy Status under US AD Law', Law \& Pol'y Int'l Bus. 30, 369, 396 (citing Lantz, R.H. (1995), 'The Search for Consistency: Treatment of NMEs in Transition under the US AD and CVD law', Am. U. J. Int'l L. \& Pol'y 10 993, 999).

157. Denton, R. (1987), 'The NME Rules of the EC's AD and Countervailing Duty Legislation', Imt' \& Comp. L. Q. 36, 236 (discussing the double-counting problem).

158. GPX Intern. Tire Corp. v. U.S., 715 F. Supp. 2d 1337 (2010) (appeal pending).

159. Appellate Body Report, United States - Definitive Anti-Dumping and Countervailing Duties on Cerrain Products from China, 91 14.123.

160. 'Agreement between the United States \& Mexico Respecting Reciprocal Trade', 23 December 1942 Art. XI, 57 Stat. 833, 845-66 (1943); see also Bhala, R. (2008), Intemational Trade Law: Interdisciplinary Theory and Practice (3rd edn), Newark, NJ: LexisNexis, 1181.

161. 'United States Suggested Charter', Art. 29, Dept. of State Pub. No. 2598 (1946): 22.

162. WTO, 'Safeguards Initiations by Reporting Member: 29 March 1995 to 30 April 2014, available 20 November 2015 at http://www.wto.org/english/tratop_e/safeg_e/SG-Initiations_By_Reporting Member.pdf.

163. WTO Agreement on Safeguards, 15 April 1994, Marrakesh Agreement Establishing the World Trade Organization, Annex 1A, Art. 2.1.

164. Ibiel, Art. 2.2.

165. Ibid, Art. 4.1(a).

166. Ibid, Art. 5.1.

167. lbid, Art. 8.1.

168. Ibid, Art. 8.2.

169. Ibid, Art. 8.3.

170. Appellate Body Report, Argentina - Safeguard Measures on Imports of Footwear, WT/DS121/AB/R, 12 January 2000.

171. Appellate Body Report, United States - Definitive Safeguard Measures on Imports of Certain Steel Prodtcts, WT/DS248, 249, 251, 252, 253, 254, 258 and 259/AB/R, 10 December 2003.

172. WTO, 'Protocol, Accession of the People's Republic of China', \$ 16, 23 Nov. 2001, (emphasis added).

173. 19 U.S.C. $\$ 2421$.

174. See Brevetti, R., 'Obama's order for safeguard tariff relief against China tire imports seen as early test', Im'l Trade Daily (BNA), 15 September 2009.

175. Alston \& Bird LLP (2009), 'President Obama authorizes first Section 421 trade remedy on Chinese products', available 15 December 2015 at http://www.lexology.com/library/detail.aspx?g=5f266bef46b0-4ce9-9ed7-be8a16b02ee7.

176. Panel Report, United States - Measures Affecting Imports of Certain Passenger Vehicle and Light Truck Tyres from China (WT/DS399/R) (panel report circulated 13 December 2010).

177. See Accession of the People's Republic of China, Decision of 10 November 2001, WT/L/43223 November 2001, Para. 16. Transitional Product-Specific Safeguard Mechanism, available 20 November 2015 at http://www.wto.org/englisil/thewto_e/acc_e/completeacc_e.htm\#chn.

178. 19 U.S.C. § $1337(\mathrm{a})(2)$.

179. 19 U.S.C. $\$ 1337(\mathrm{a})(3)$

180. Report of the Panel, United States - Section 337 of the Tariff Act of 1930, L/6439-36S/345, 16 January 1989.

181. TRIPS Art. $41(2)$.

182. Ibid, Art. 51 .

183. 19 U.S.C. § $1337(\mathrm{~d})$.

184. 19 U.S.C. $\$ 1337(\mathrm{~b}-\mathrm{c})$.

185. 19 U.S.C. $\$ 2411$ et seq.

186. See, e.g., Eizenstat, J.L. (1996), "The Impact of the World Trade Organization on Unilateral U.S. Trade Sanctions under Section 301 of the Trade Act of 1974: A Case Study of the Japanese Auto Dispute and the Kodak-Fuji Dispute', Emory Int'l L. Rev. 11, 137.

187. Publ. L. $93-618,19$ U.S.C. \& 2411.

188. Panel Report, United States - Sections 30I-310 of the Trade Act of 1974, WT/DS152/R, 27 January 2000.

189. See, e.g., Sykes, Alan O. (1992), 'Constructive Unilateral Threats in International Commercial Relations: The Limited Case for Section 301', L. \& Pol'y Imt'l Bus 23, 263. 
190. 19 U.S.C. $\$ 2242$.

191. USTR, '2014 Special 301 Report,' April 2014, available 20 November 2015 at http://www.ustr.gov/ sites/default/files/USTR\%202014\%20Special\%20301\%20Report\%20to\%20Congress\%20FINAL.pdf.

192. Ibid, at $30-31$. 